An Affirmative Action/Equal Opportunity Employer

Edited by Glenda Cremer, G Division

This work was supported by the US Department of Energy, Division of Geothermal Energy.

HDR Site Selection Report No. 2

DISCLAIMIR

This report was prepared as an account of work sponsored by an agency of the United States Government. Neither the United States Government nor any agency thereof, nor any of their employees, makes any warranty, express or implied, or assumes any legal liability or responsibility for the accuracy, completeness, or usefulness of any information, apparatus, product, or process disclosed, or represents that its use would not infringe privately owned rights. Reference herein to any specific commercial product, process, or service by trade name, trademark, manufacturer, of otherwise, does not necessarily constitute or imply its endorsement, recommendation, or favoring by the United States Government or any agency thereof. The views and opinions of authors expressed herein do not necessarily state or reflect those of the United States Government or any agency thereof. 


\title{
Hot Dry Rock Geothermal Potential of Roosevelt Hot Springs Area: Review of Data and Recommendations
}

\author{
Jennifer East*
}

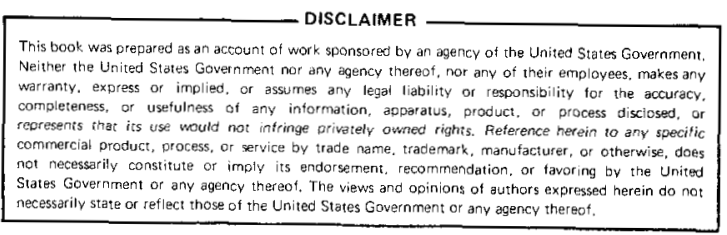

*Consultant. University of Alaska, Geoscience Department, Fairbanks, AK 99701.

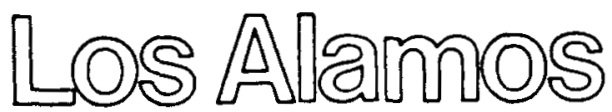

Los Alamos National Laboratory 
HOT DRY ROCK GEOTHERMAL POTENTIAL OF ROOSEVELT HOT SPRINGS AREA:

REVIEW OF DATA AND RECOMMENDATIONS

by

Jennifer East

\begin{abstract}
The Roosevelt Hot Springs area in west-central Utah possesses several features indicating potential for hot dry rock (HDR) geothermal development. The area is characterized by extensional tectonics and a high regional heat flow of greater than $105 \mathrm{~mW} / \mathrm{m}^{2}$. The presence of silicic volcanic rocks as young as 0.5-0.8 Myr and totaling $14 \mathrm{~km}^{3}$ in volume indicates underlying magma reservoirs may be the heat source for the thermal anomaly.

Several hot dry wells have been drilled on the periphery of the geothermal field. Information obtained on three of these deep wells shows that they have thermal gradients of $55-60^{\circ} \mathrm{C} / \mathrm{km}$ and bottom in impermeable Tertiary granitic and Precambrian gneissic units. The Tertiary granite is the preferred HDR reservoir rock because Precambrian gneissic rocks possess a well-developed banded foliation, making fracture control over the reservoir more difficult.

Based on a fairly conservative estimate of $160 \mathrm{~km}^{2}$ for the thermal anomaly present at Roosevelt Hot Springs, the area designated favorable for HDR geothermal exploration may be on the order of seven times or more than the hydrogeothermal area currently under development.
\end{abstract}

\title{
I. INTRODUCTION
}

The Roosevelt Hot Springs area is located in Beaver County, west-central Utah, about $14 \mathrm{~km}$ northeast of the city of Milford. It lies about $1 \mathrm{~km}$ above the floor of Milford Valley on the western flank of the Mineral Mountains, the site of the largest exposed intrusive body in the state. 
At one time, Roosevelt Hot Springs was a resort area that contained thermal springs discharging silica-rich waters. By 1966 spring flow had ceased, yet Roosevelt still contains active fumaroles depositing sublimates with a slight hydrogen sulfide odor.

Based on temperature data from 53 shallow drill holes, Wilson and Chapman (1978) estimated the hydrothermal resource area as being $6 \mathrm{~km}$ 1ong by $1.5 \mathrm{~km}$ wide at a depth of $450 \mathrm{~m}$. Several companies are currently working within this field. Seven production wells have been drilled with a maximum flow capability of about $4.5 \times 10^{5} \mathrm{~kg}$ of combined vapor and liquid per hour. Bottomhole temperatures are as high as $260^{\circ} \mathrm{C}$, with well depths ranging from 300 to $2234 \mathrm{~m}$ (Evans and Nash, 1978; Parry and others, 1977).

\section{REGIONAL STUDIES}

\section{A. Geology and Geophysics}

The Roosevelt Hot Springs area is at the eastern margin of the Basin and Range province where this province is transitional with the Colorado Plateau (Fig. 1). The physiographic boundary between these two provinces has been placed along major fault zones to the east and southeast, such as the Hurricane, Sevier, and Tushar Faults, which are considered as southern extensions of the Wasatch Front (Fig. 2). However, based on seismic refraction, geomagnetic variation, geochemistry, and geologic structures, the major lateral change of crustal geophysical parameters between the Basin and Range-Colorado Plateau occurs 50 to $100 \mathrm{~km}$ east of the actual physiographic boundary (Shuey and others, 1973; Keller and others, 1975).

This transition zone between the Colorado Plateau and Basin and Range province is characterized by thin crust, approximately $25 \mathrm{~km}$ thick, a $10 \mathrm{w} P_{n}$ velocity of $7.5 \mathrm{~km} / \mathrm{s}$ and a crustal low-velocity layer in the general depth range of 8-15 km. These features suggest that a mantle upwarp area, at least $80 \mathrm{~km}$ wide and of unknown length, exists beneath the transition zone (Keller and others, 1975).

It has been predicted that the high heat flow characteristic of the Bas in and Range province (described later) extends eastward beyond the Basin and Range-Colorado Plateau physiographic boundary (Shuey and others, 1973). Current heat flow work within the transition zone has verified this prediction (John Bode11, University of Utah, personal communication, 1980). The southern 


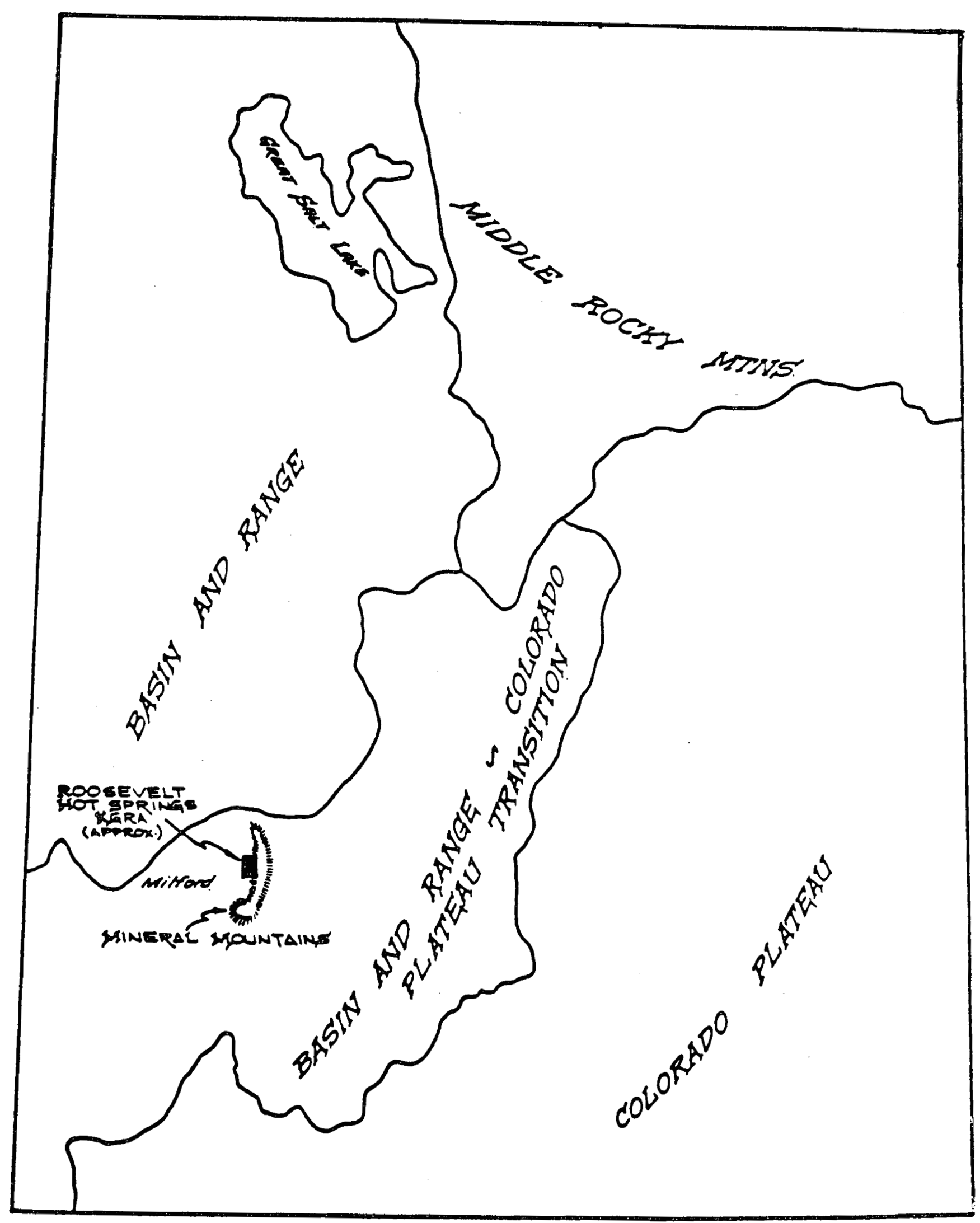

Fig. 1. Location of study area and physiographic subdivisions of Utah. After Gibbet and Nelson, 1980.

3 


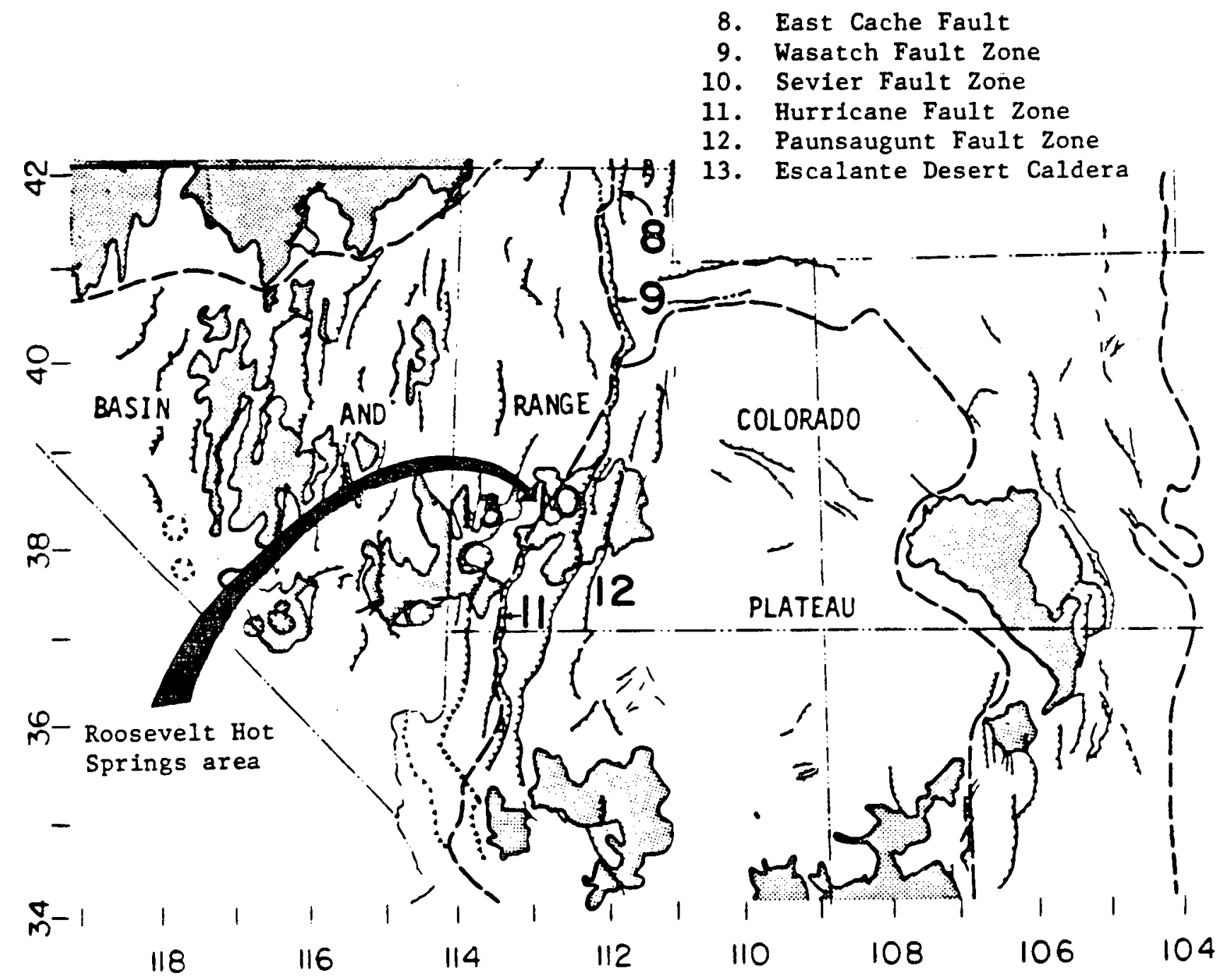

Fig. 2. Generalized late Mesozoic-Cenozoic map of Intermountain West taken from King's tectonic map of North America (1969) and U.S. Geological Survey's (1962) tectonic map of United States. Stippled pattern = Tertiary and Quaternary volcanic rocks; heavy lines = physiographic boundaries. Late Cenozoic and Quaternary faults shown with hachures on downthrown side. After Smith and Sbar, 1974. 
part of the Intermountain Seismic Belt (ISB) of Smith and Sbar (1974) is also coincident with the Basin and Range-Colorado Plateau boundary. The Intermountain Seismic Belt is a 1300-km-long and 100-km-wide zone of pronounced earthquake activity that extends northeast from Arizona into Utah, and then north into eastern Idaho and western Montana (Fig. 3). Two secondary westerly trending seismic zones also occur in the intermountain region. The southern zone extends eastward $200 \mathrm{~km}$ from southern Nevada into ssouthwest Utah, intersecting the ISB and the Hurricane Fault near Cedar City, Utah.

Roosevelt Hot Springs is located near the western edge of the ISB where the trend changes from northeast to north. This east-trending zone of active seismicity crosses the regional tectonic grain of north-south Basin and Range block faulting; yet it is coincident with an east-trending zone of Tertiary rhyolites and calderas that extend from the Tushar Mountains, which are the range immediately east of the Mineral Mountains, into southern Nevada. This change in trend of the ISB also corresponds to a major east-west gravity linear that cook and others (1975) think represents a relic transform fault of late-Mesozoic early-Cenozoic age.

B. Regional Heat Flow

The Bas in and Range province possesses an average heat flow of $92+$ $8 \mathrm{~mW} / \mathrm{m}^{2}$ in contrast with the $50 \pm 8 \mathrm{~mW} / \mathrm{m}^{2}$ average of the Colorado Plateau (Sass and others, 1980). Two regions have been identified with in the Utah Basin and Range province that show elevated heat flow (Chapman and others, 1978). The northernmost region is referred to as the South Bonneville Anomaly. It trends roughly northwest near latitude $40^{\circ} \mathrm{N}$.

The southern region of elevated heat flow trends northeast from the Escalante Desert of southwest Utah to the Cove Fort-Sulphurdale geothermal area of west-central Utah. This region possesses an average heat flow of greater than $105 \mathrm{~mW} / \mathrm{m}^{2}$ and includes several known Geothermal Resource Areas (KGRA) (Figs. 4 and 5). The heat flow anomaly was delineated on the bas is of regional measurements excluding the geothermal resource areas (Chapman and others, 1978). Based on the heat flow map of Sass and others (1980), the Roosevelt Hot Springs KGRA is marginal to this 200-km-long zone, which ends northeast of Roosevelt near the Cove Fort-Sulphurdale geothermal area. 


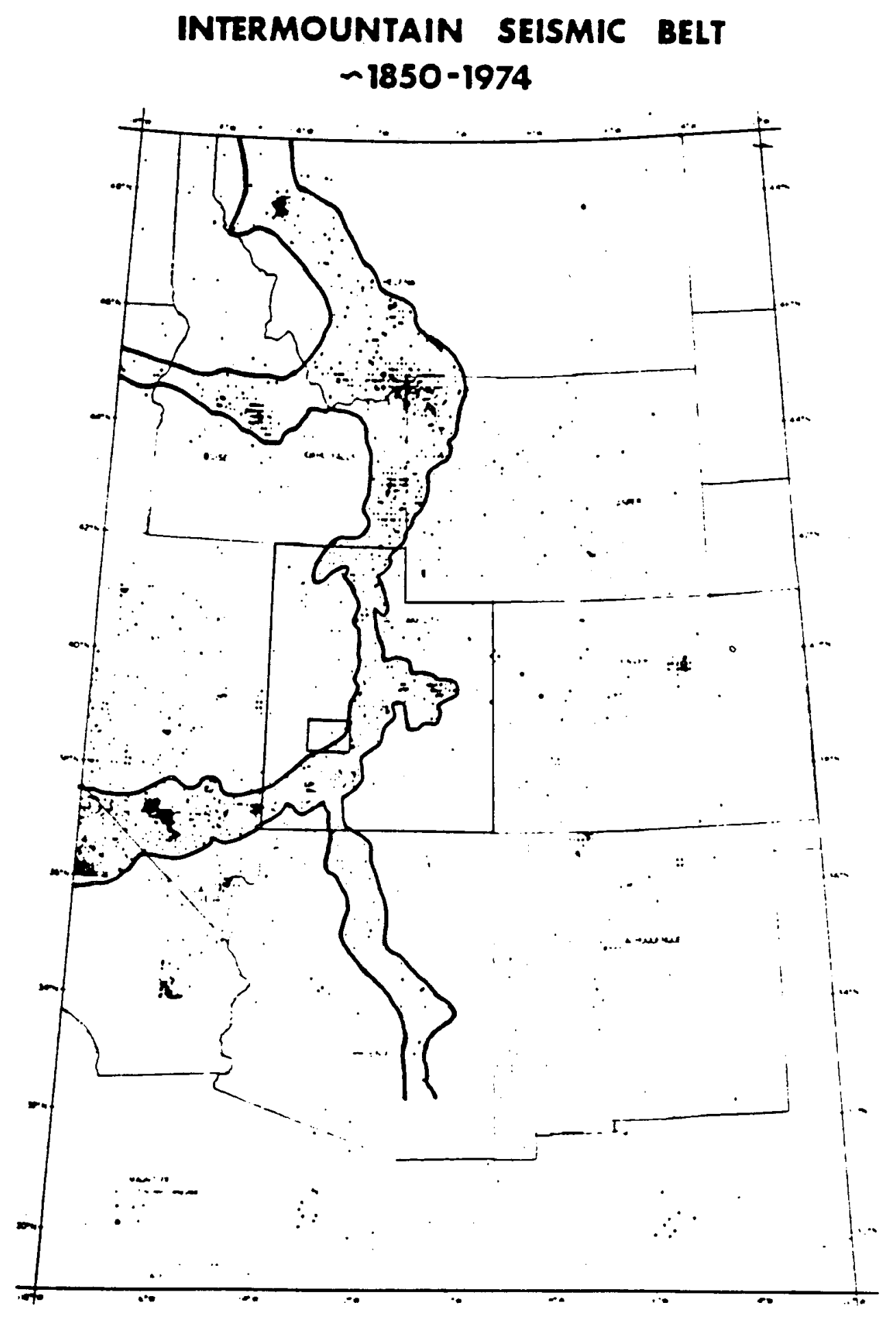

Fig. 3. Index map and regional seismicity. Regional seismicity taken from Smith, (1975). Box outlines Cove Fort and Roosevelt Hot Spring area. After 01sen and Smith, 1976. 


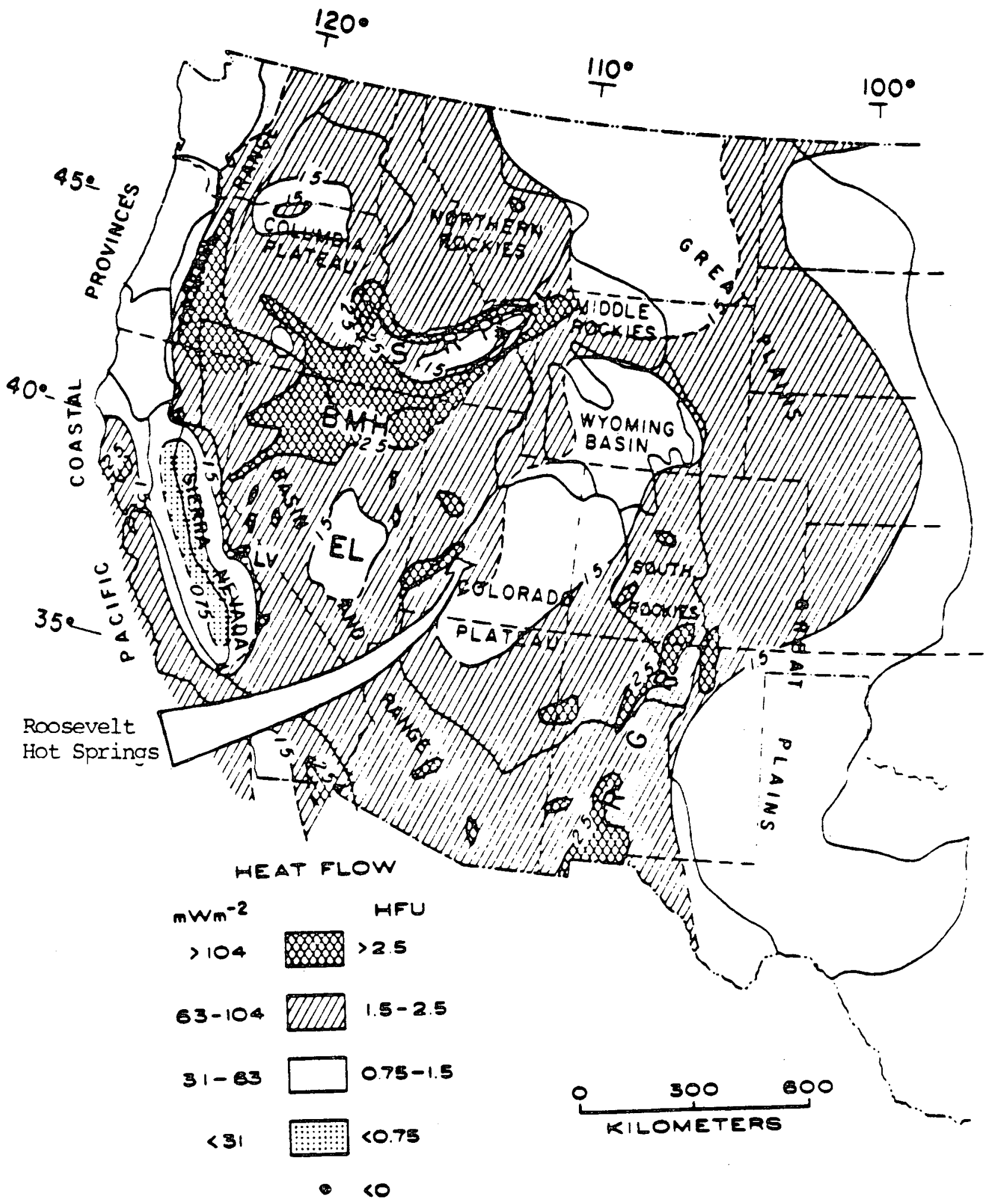

Fig. 4. Western United States showing heat-flow contours (in HFU), heat-flow provinces, and major physiographic divisions. (SRP, Snake River Plain; BMH, Battle Mountain High; El, Eureka Low; RGR, Rio Grande rift zone; Y, Yellowstone; LV, Long Valley.) ( $\left.1 \mathrm{HFU}=41.8 \mathrm{~mW} / \mathrm{m}^{2}.\right)$ After Sass and others, 1980. 


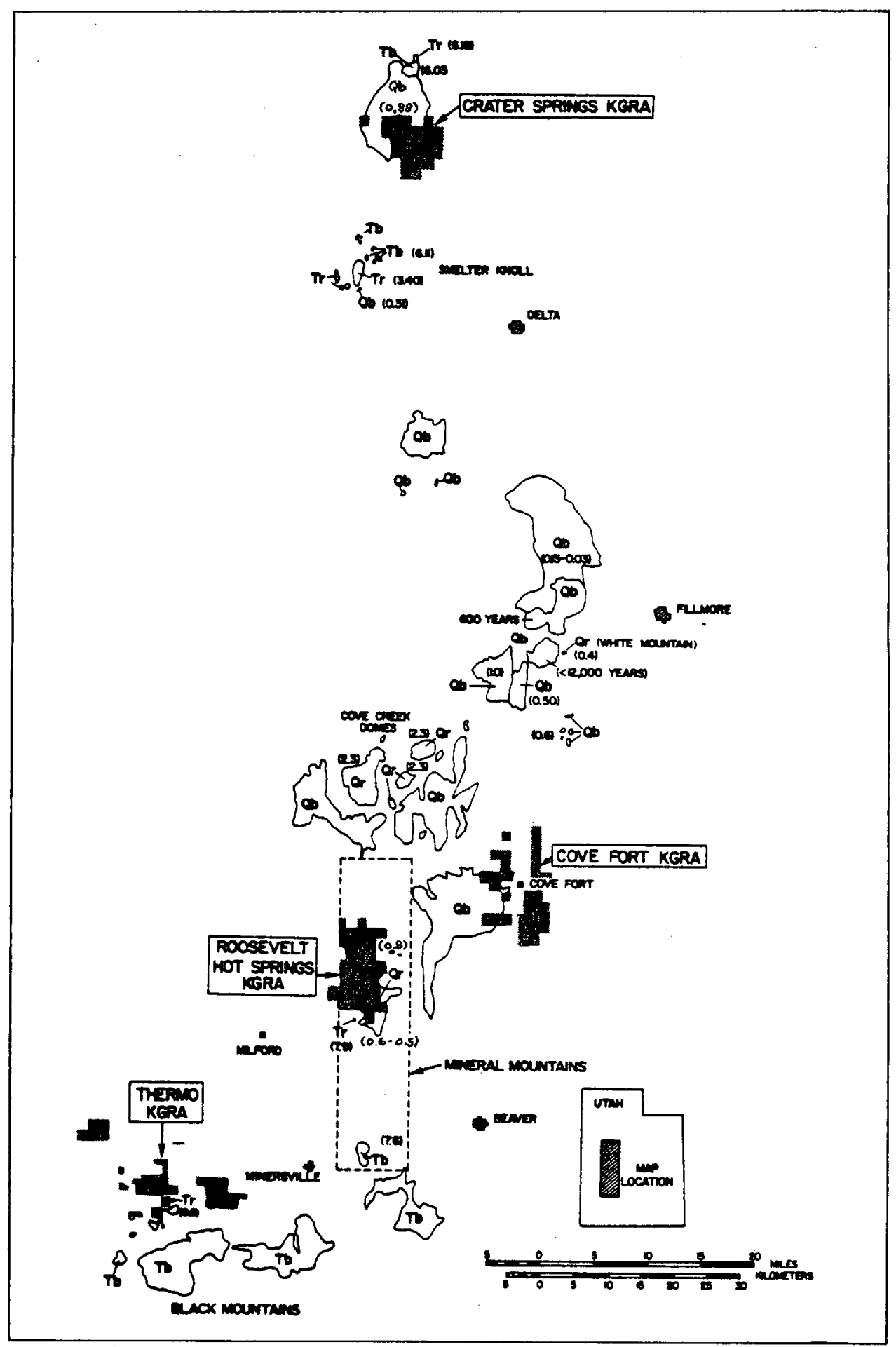

Fig. 5. Location of KGRA's in west-central Utah. Tertiary and Quaternary volcanic outcrops are shown with accompanying age dates in Myr. $\mathrm{Tb}=$ Tertiary basalt, $\mathrm{Tr}=$ Tertiary rhyolite, $Q b=$ Quaternary basalt, $Q r=$ Quaternary rhyolite. After Parry and others, 1977. 
III. LOCAL GEOLOGY

The Mineral Mountains are a 45-km-long, 12-km-wide horst, characteristic of the Basin and Range province. North-striking bounding faults define its western and eastern margins. Milford Valley, a northern extension of the Escalante Desert, lies to the west. Alluvium in Milford Valley has a minimum depth of $1 \mathrm{~km}$, based on drill hole information (Carter and Cook, 1978).

The northern and southern portions of the Mineral Mountains are comprised mainly of Precambrian metamorphic and sedimentary rocks of Paleozoic to Mesozoic age. Tertiary-age granitic rocks dominate the central section, bounded on the north by the County Line Fault and on the south by the Cave Canyon Fault (Fig. 6). These two faults correspond with well-defined east-west trending magnetic gradients (Carter and Cook, 1978).

A probable major structural feature in the Milford area is an eastnortheast trending lineation, designated by Crosby (1973) as the Black Rock offset. It extends $90 \mathrm{~km}$ from the Tushar Mountains to the San Francisco Mountains, and defines the northern edge of the transverse igneous belt mentioned earlier. The offset exhibits predominate right-lateral strike-slip displacement.

In the northern Mineral Mountains the County Line Fault probably corresponds in part with the Black Rock Offset. East-west trending magnetic and gravity gradients cross the County Line Fault and continue westward through the alluvium of Milford Valley. Carter and Cook (1978) interpreted these gravity and magnetic trends as indicating the northern terminus of one large or several smaller intrusives. These intrusives form the floor of the Milford Valley south of the County Line Fault-Black Rock Offset.

North-trending, normal faults offset Precambrian and Tertiary rocks along the western edge of the central Mineral Mountains. Other north to northeasttrending faults such as the Opal Mound Fault (the Dome Fault of Petersen, 1975) were mapped on the basis of linear trends of hot spring deposits, and displacements in alluvial fan surfaces (Petersen, 1975).

The central Mineral Mountains are a structural high that expose highly deformed Precambrian metamorphic rocks and the Mineral Mountains pluton, and cover nearly $250 \mathrm{~km}^{2}$. Rb-Sr systematics by Lipman and others (1978) suggest the maximum age of the pluton is $35 \mathrm{Myr}$, yet the granite is assumed to 


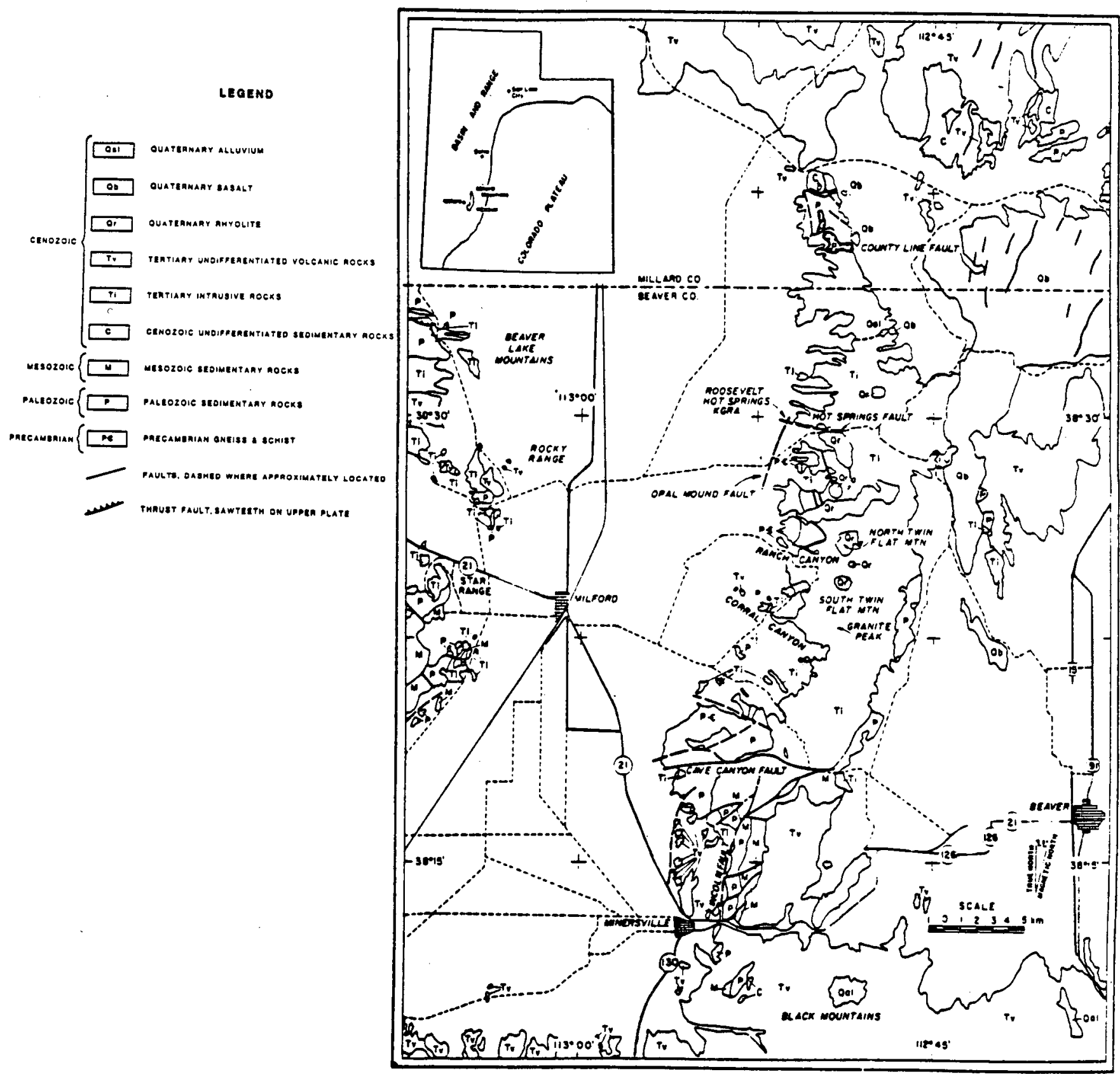

Fig. 6. General geology of the Mineral Mountains. Modified from Carter and Cook, 1978; Nielson and others, 1978. After Yus as and Bruhn, 1979. 
be 20-25 Myr based on K-Ar dates on similar rocks to the west in the San Francisco and Wah Wah Mountains (Lemmon and others, 1973).

Other units exposed in the central Mineral Mountains include Quaternary hot spring deposits of opaline and chalcedonic sinter, and late Tertiary rhyolite and Quaternary silicic volcanics. K-Ar dating of the Quaternary rhyolites yields ages of approximately 0.5 to 0.8 Myr (Lipman and others, 1978).

A few small outcrops of vesicular porphyritic basalt are present near the northern end of the range. The outcrops consist of small flows with ropy flow tops and two small spatter cones that overlie bedrock and alluvium. The basalt cones are only slightly eroded and the ropy flow tops and spatter cones are well preserved, suggesting that most are less than 10000 years $01 d$ (Sibbett and Nielson, 1980). Several extensive basalt fields lie north and east of the Mineral Mountains. They are roughly contemporaneous with, and younger than, the rhyolite of the Mineral Mountains (Condie and Barsky, 1972; Hoover, 1974). Basaltic volcanism was initiated about 1 Myr ago in the Black Rock field to the north. The Cove Fort field to the west is recognized as one of Utah's youngest lava fields, dated at less than 10000 years. This bimodal assemblage of basalt and rhyolite, associated with continental regions, has been recognized widely in the western United States in upper Cenozoic volcanic sequences (Christiansen and Lipman, 1972).

\section{A. Stratigraphy: Precambrian}

Precambrian gneiss and schist form an irregular, 1-km-wide belt along the eastern edge of the Roosevelt KGRA. These metamorphic rocks were divided into five mappable units by Nielson and others (1978). The units include banded gneiss, hornblende gneiss, quartzite, sillimanite schist, and biotite gneiss. However, recent age dating now suggests a Tertiary age for the hornblende gneiss and biotite gneiss units (Nielson, University of Utah Research Institute, personal communication, 1980).

The banded gneiss is the oldest and most extensive unit. It consists of highly variable interlayered gneiss, schist, and a migmatite with conspicuous light and dark layers. This banding is thought to refiect relict sedimentary layering. The gneiss possess a well-developed schistosity and isoclinal folding with northeast-plunging lineation on schistosity planes (Nielson and 
others, 1978). The banded gneiss has been intruded by the hornblende gneiss and the Tertiary plutonic phases.

The hornblende gneiss is a coarse-grained foliated granodiorite that intrudes the banded gneiss to the west and is intruded by Tertiary plutonic rocks to the east. It commonly displays a weak foliation, yet locally, hornblende gneiss may show a strong foliation and lineation, with alignment of hornblende grains.

The other three units, the metaquartzite, sillimanite schist, and biotite gneiss are of limited extent and occur mainly as inclusions within the banded gneiss and hornblende gneiss.

\section{B. Tertiary}

Tertiary felsic rocks of the Mineral Mountains pluton underlie most of the central portion of the Mineral Mountains. Intrusive rocks in the San Francisco and Wah Wah Mountains to the west yield dates of 20-23 Myr for quartz monzonite rocks and 27-29 Myr for granodiorite rocks (Lemmon and others, 1973). The Mineral Mountains pluton is assumed to be of similar age. $\mathrm{K}$-Ar dates show ages of roughly 10-12 Myr for the Mineral Mountains pluton (Armstrong, 1970), but a thermal event approximately 10 Myr ago probably has reset these dates.

Nielson and others (1978) have identified five major felsic phases of the batholith, with relative ages documented by cross-cutting relationships. In chronologic order the five phases are: quartz monzonite, porphyritic granite, syenite, granite, and fine-grained granite. The pluton has been subsequently cut by a suite of mafic and aplitic dikes, as well as by Quaternary silicic volcanics, which include flows, pyroclastics, and domes.

Felsic plutonic phases are typically medium to coarse-grained. Biotite and hornblende are varietal minerals. Sphene, apatite, magnetite, and ilmenite are minor accessories in most units. Alteration of the phases is minor, with some formation of sericite associated with feldspars and some chlorite after biotite.

The quartz monzonite is the earliest and most abundant phase of the Mineral Mountains pluton as exposed in the Roosevelt Hot Springs area. It intrudes Precambrian gneiss and is in turn intruded by all other Tertiary felsic phases. The quartz monzonite is typically massive, however near its 
contact with the Precambrian rocks it displays numerous xenoliths and a pervasive shear foliation, which generally trends north-south.

The later Tertiary felsic phases are only briefly mentioned. They display strong textural and compositional affinities. Fine- to medium-grained granite occurs as a major late-stage dike-forming unit followed by minor microdiorite, diabase, and rhyolite dikes.

Younger Tertiary silicic volcanic rock units (K-Ar date $7.90 \pm 0.3$ Myr) occur in lower Corral Canyon south of Roosevelt KGRA. The volcanics are highly dissected and dissimilar petrographically from the younger rhyolite domes located along the crest of the range. Field work by Evans and Nash (1978) indicates that these are older rhyolites and may be the remnant of an earlier dome or set of domes. However, Sibbett and Nielson (1980) describe the volcanic units as a flow of porphyritic quartz latite. It may be that a thermal event at 10 Myr produced these late Tertiary silicic volcanics and reset many of the dates on rocks of the Mineral Mountains pluton.

\section{Quaternary}

A suite of Pleistocene rhyolitic volcanic rocks extends discontinuously for about $15 \mathrm{~km}$ along the crest of the Mineral Mountains. This suite was initiated by eruption of two low-viscosity rhyolite flows, followed by airfall pumice and non-welded ash flows. The youngest activity produced 12 viscous rhyolite domes and minor lava flows. $K-A r$ radiometric dates indicate this volcanic activity lasted from 0.8 to 0.5 Myr b.p. (Lipman and others, 1978).

Smith and Shaw (1975) hypothesized that young rhyolites such as these may indicate the presence of shallow magma reservoirs that could serve as the heat source for the geothermal system present at the Roosevelt Hot Springs area. The KGRA is located $2-\mathrm{km}$ west of the nearest Quaternary rhyolite outcrop.

The Bailey Ridge and Wildhorse Canyon nonporphyritic obsidian flows are the oldest of the Quaternary rhyolites. Radiometric dating of the Bailey Ridge flow gives an age of $0.77 \pm 0.08 \mathrm{Myr}$ (Lipman and others, 1978). Paleomagnetic, chemical, and morphological similarities between the Bailey Ridge and Wildhorse Canyon flow suggest a similar age. Both flows are 
currently about $3 \mathrm{~km}$ long and about $80 \mathrm{~m}$ thick, and were originally as much as $100 \mathrm{~m}$ thick. They are nonporphyritic and obsidian-rich but commonly possess devitrified cores.

Pyroclastic units occupy an intermediate position in the stratigraphic sequence. Explosive eruptions deposited air-fall tuff (some was reworked by water), as well as nonwelded ash flow tuffs. Principal exposures are in Ranch Canyon. The tuffs are generally light colored, white to tan and poorly consolidated. A K-Ar date on a contained obsidian clast gives a maximum age for the pyroclastics of $0.68 \pm 0.04$ Myr (Lipman and others, 1978).

Twelve rhyolite domes occur along the crest of the range, extending discontinuously for about $15 \mathrm{~km}$. The domes form some of the highest topographic points in the Mineral Mountains. Individual domes are as much as $1 \mathrm{~km}$ across at the base and as much as $250 \mathrm{~m} \mathrm{high} \mathrm{(Lipman} \mathrm{and} \mathrm{others,} \mathrm{1978).} \mathrm{Smal1,} \mathrm{stub-}$ by flows extend out from some of the domes.

Based solely on the degree of dissection it appears the oldest domes are North and South Twin Flat Mountains and the youngest domes are Bearskin and Little Bearskin Mountain. Well-dissected domes exhibit a basal black vitrophyre zone that grades upward into devitrified rock. Upper portions of the less dissected domes consist of blocks of tan perlitic glass, remnants of the original brecciated frothy carapace. The steeply dipping flow layering and ramp structures in the interior of the domes show a marked contrast in viscosity, compared with flow structures in the older lavas of Bailey Ridge and Wildhorse Canyon (Lipman and others, 1978). All the domes contain phenocrysts of quartz, oligoclase, alkali feldspar, biotite, and iron-titanium oxides.

Age determinations on obsidian from Bearskin Mountain and sanidine from Little Bearskin Mountain have yielded K-Ar ages of $0.58 \pm 0.12 \mathrm{Myr}$ and $0.53 \pm$ 0.05 Myr, respectively (Lipman and others, 1978).

Several magma-genes is models have been proposed for the Pleistocene rhyolites of the Mineral Mountains. One model involves differentiation from a parent granitic magma related to the Mineral Mountains pluton. The second model attributes rhyolitic magmatism to a later event independent of the pluton, yet localized where the crust was still hot from the earlier plutonic event (Lipman and others, 1978). Evans and Nash (1978) propose that the high amount of basaltic volcanism to the north and southeast of the Mineral 
Mountains, in combination with a high regional heat flow of $92 \mathrm{~mW} / \mathrm{m}^{2}$ or greater caused crustal melting that produced a separate (later) rhyolitic magma .

Evans and Nash (1978) have also determined equilibration temperatures for the Quaternary rhyolite using the iron-titanium oxide geothermometer of Buddington and Lindsley (1964). The results indicate eruption temperatures of $740-785^{\circ} \mathrm{C}$ for the 01 der Quaternary obsidian flows and $635-665^{\circ} \mathrm{C}$ for the younger pyroclastic rocks and rhyolite domes. Similar temperatures were obtained using the two-feldspar geothermometer. Evans and Nash (1978) speculate that the domes and flows are genetically related and that the rhyolite of the domes was derived by differentiation of the magma that produced earlier obsidian flows. Chemical and mineralogic data also substantiate a single magma source with the fractionation of feldspar (Parry and others, 1977).

D. Hot Spring Deposits

Hot spring deposits in the Roosevelt KGRA include both opaline and chalcedonic sinter and silica-cemented alluvium. The Opal Mound and other hot spring deposits are either localized along the north trending Opal Mound Fault or in the proximity of Roosevelt Hot Springs. Hot spring deposits along the Opal Mound Fault are vertically displaced at least $3.5 \mathrm{~m}$ (Petersen, 1975).

\section{E. Structure}

Based on work by Nielson and others (1978) the Roosevelt KGRA is believed to be dominated by four major fault systems. These are in order of age: 1) large-scale faults which dip at shallow angles to the west, 2) northwest trending fault zones probably related to the low-angle faults, 3) east-west steeply dipping structures and, 4) north to northeast-trending Bas in and Range normal faults which localized the hot spring activity (Fig. 7).

The large-scale faults generally trend northwest and can be traced discontinuously for up to $3 \mathrm{~km}$. These low-angle normal faults offset both Precambrian metamorphic and Tertiary granitic rocks. Fault planes appear to flatten at depth and the fault zones are often marked by mylonites or by intense brecciation. These low-angle faults are similar to those described as denudation faults by Armstrong (1972) and may also be referred to as gravity slide blocks. They were probably formed during uplift of the Mineral Mountains (Nielson and others, 1978). According to Sibbett and Nielson 


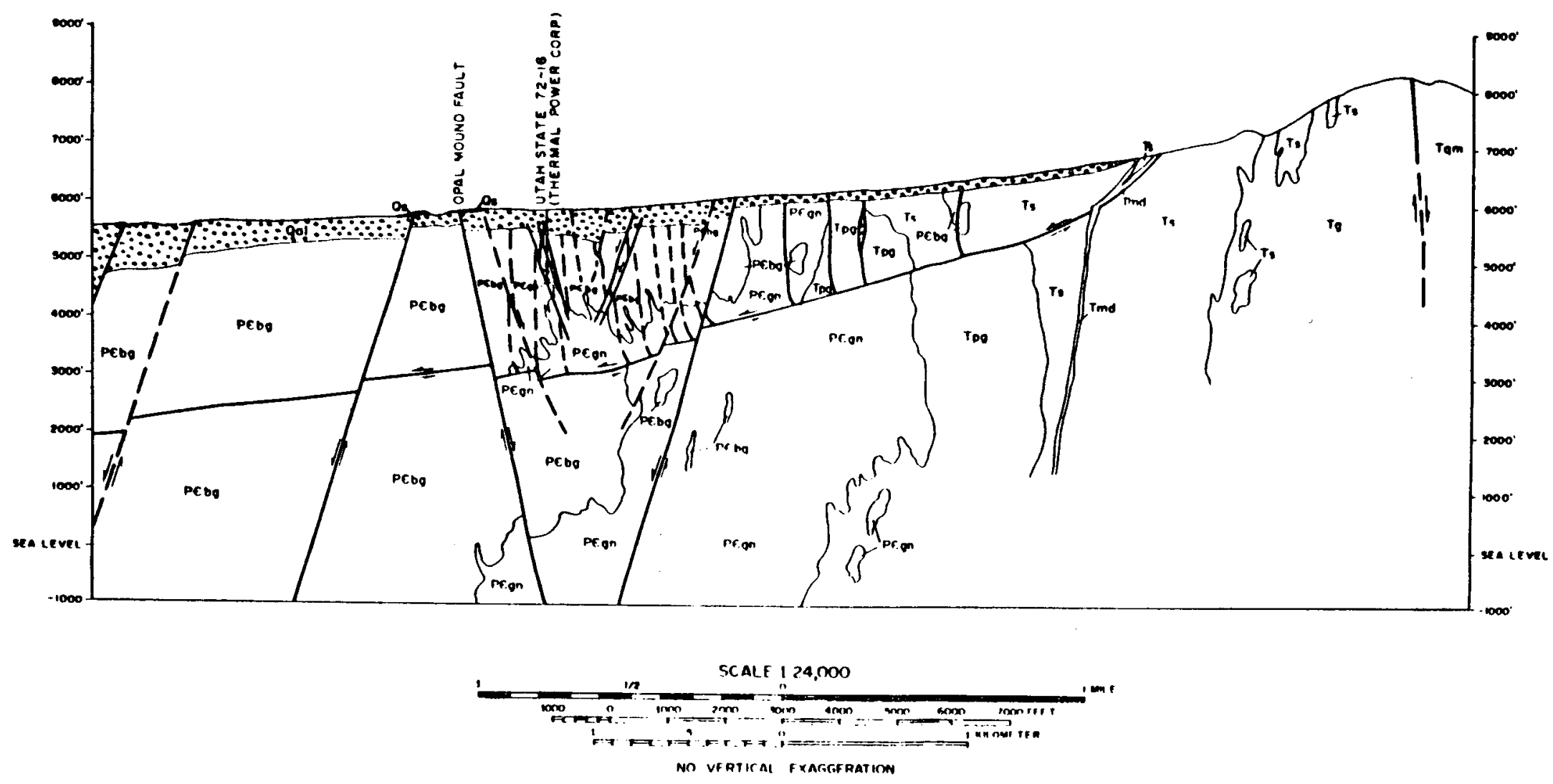

Fig. 7. East-west cross section through Roosevelt Hot Springs geothermal field, illustrating fault relationships. After Nielson and others, 1978. 
(1980), the first low-angle faults probably formed near the pluton-country rock contact or a few feet below this along cooling fractures with in the pluton. Later denudation faults are thought to have formed deep within the pluton.

The second fault system is confined to the upper plates of the major low-angle faults. They form zones of northwest-trending, high-angle faults which dip steeply either east or west. Nielson and others (1978) conclude that northwest trending faults were developed in the upper plate in response to differential movement of the plate during displacement. Thin sections of fault breccia and mylonite suggest more than one period of movement of lowangle faults (Sibbett and Nielson, 1980).

The third fault system includes steeply dipping east-west normal faults. The most prominent of these is the Negro Mag fault system (Hot Springs Fault of Yus as and Bruhn, 1979) sub-parallel to Negro Mag Wash.

The fourth and youngest set of faults in the KGRA trend north- to northnortheast and dip at high angles. The best exposed is the Opal Mound Fault with associated silicious sinter deposits. The Opal Mound Fault forms the western boundary of the hydrothermal reservoir. A north-south trending magnetic high and resistivity low follows the Opal Mound Fault south of Negro Mag Wash (Carter and Cook, 1978; Nielson and others, 1978). North of the wash there is a change in trend of the resistivity low to the northwest and tracing of the Opal Mound Fault becomes speculative (Nielson and others, 1978).

Detailed gravity surveys conducted by the University of Utah in 1974 and 1975, showed that the Opar Mound Fault is just one of several north trending normal faults in the area (Crebs and Cook, 1976; Thangsuphanich, 1976). Gravity modeling by Ward and others (1978), and 01son and Smith (1976) show repeated down faulting to the west of the Opal Mound Fault. Gertson and Smith (1979) have mapped a fault in alluvium about $1.5 \mathrm{~km}$ west of the 0pal Mound. This fault is believed to be the main range-front fault on the west side of the Minerar Range.

\section{GEOPHYSICAL STUDIES}

Geophysical studies help in understanding hydrothermal systems as well as the HDR potential present in the Roosevelt Hot Springs area. Seismic, gravity, and magnetic studies have defined the regional setting; resistivity 
and heat flow were used to localize the convective hydrothermal system, whereas seismic, magnetotelluric, gravity, and magnetics were used in an attempt to locate the source of heat.

A. Seismic

Microearthquake monitoring around the Roosevelt Hot Springs KGRA during 1974 and 1975 and again from 1977 to 1978, revealed that virtually all earthquakes occurred along a northeast-southwest trend from north of Cove Fort through the Mineral Range. The strike of the belt appears parallel to, but east of, the Opal Mound fault zone. Earthquake activity in the Roosevelt Hot Springs area was minimal in comparison with the Cove Fort-Sulphurdale area $25 \mathrm{~km}$ to the east, where earthquake activity was characterized by primarily shallow, less than 5-km focal depths (01son and Smith, 1976).

A teleseismic P-delay study was recently completed by the $U$. $S$. Geological Survey (USGS) for the Roosevelt and Cove Fort regions (Robinson and Iyer, 1979). Two elongate zones were detected beneath the Mineral Mountains, which were interpreted as pipes of partially molten material. The deeper zone of the two extends from the mantle to approximately $10-\mathrm{km}$ depth. The smaller low-velocity zone is found at a depth of $5 \mathrm{~km}$ or less.

Weschler and Smith (1979), however, suggest that the delays in P-wave travel times could be due to the fractured nature and possible fluid-filled porosity of the western edge of the Mineral Mountains pluton. They also suggest that low velocities could be in response to a compositional change from granite to gneiss.

Fault-plane solutions for the Cove Fort earthquakes demonstrate oblique normal faulting with west to west-northwest directions of the minimum compressive stress (Ward and others, 1977). This stress direction is consistent with general east-west extension of the eastern Great Basin.

\section{B. Gravity and Magnetics}

This summary of gravity and magnetic work at Roosevelt is primarily from Ward and others (1977). Figure 8 shows the terrain-corrected Bouguer gravity anomaly map based on about 700 stations measured during 1974 through 1976. The generally north-trending gravity contours with pronounced gradients adjacent to the western margin of the Mineral Mountains indicate Basin and Range faulting, that formed the eastern margin of the Milford Valley graben 


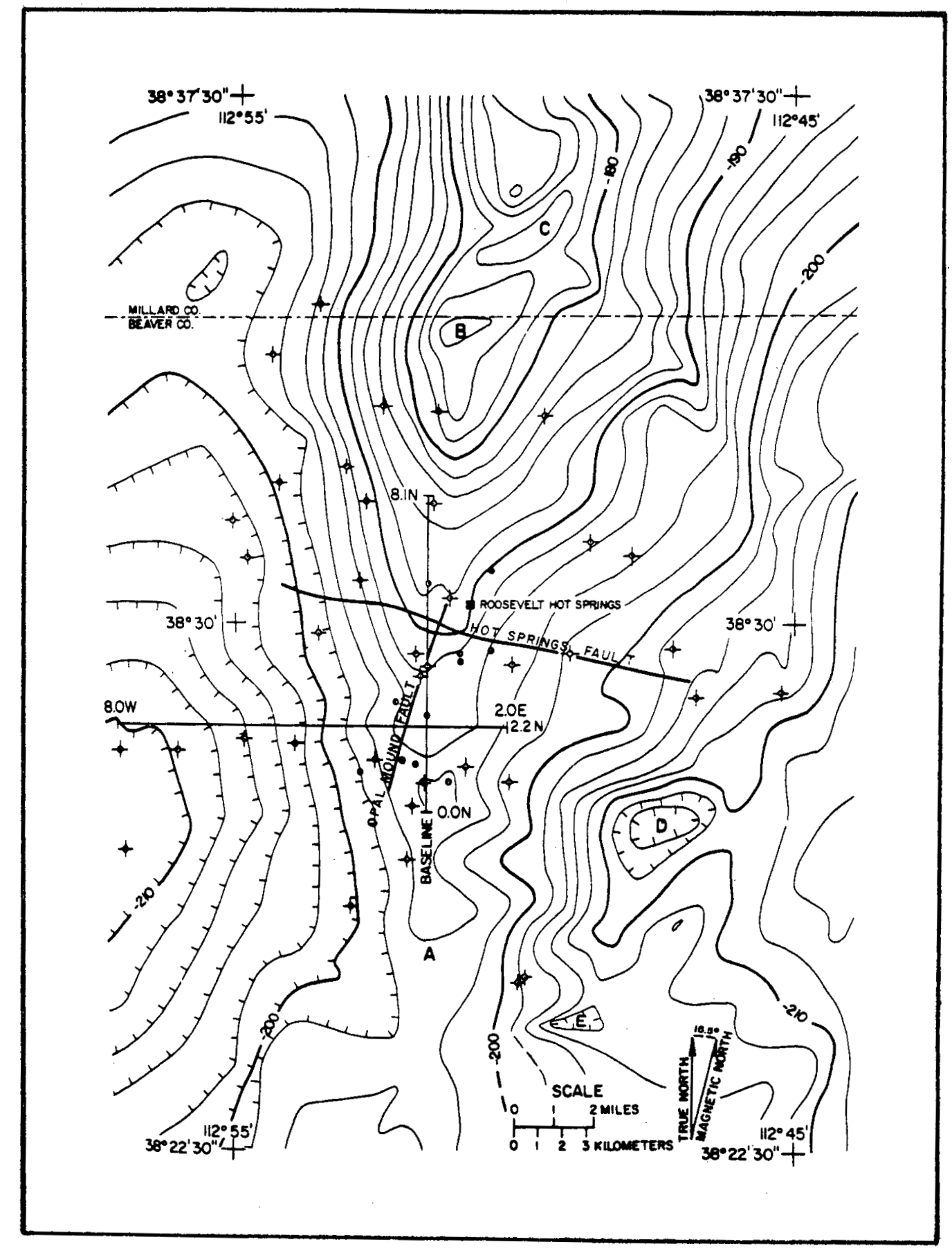

Fig. 8. Terrain-corrected Bouguer gravity anomaly map of the Roosevelt Hot Springs area. Contour interval $=2 \mathrm{mgal}$. Well designations: solid circle--productive wel1; plain open circle--non-productive well; open circle, with crosses-thermal gradient well. Letter designations are described in text. After Ward and others, 1977. 
that appears as a gravity low along the western part of the map. About 2-km north of the Millard-Beaver county line, a fault zone occurs (C of Fig. 8) where the Mineral Mountains pluton terminates against Paleozoic rocks. Here the northern gravity $h i g h$ is separated into two gravity highs that are rightlaterally offset about $2 \mathrm{~km}$ in the intervening gravity saddle. This eastward trending lineation corresponds with the Black Rock Offset of Crosby (1973) and passes across the County Line Fault. In the southern part of the gravity map (D of Fig. 8) is a pronounced north-northeast trending elongate gravity $10 \mathrm{w}$, about $8 \mathrm{~km}$ in length, which consists of two gravity lows (D and $E$ of Fig. 8 ), that correspond with a series of volcanic domes, including Bearskin and Little Bearsk in Mountains, and North and South Twin Flat Mountains. This gravity low may indicate a low-density intrusive at shallow depth $(2 \mathrm{~km})$ beneath these domes, but more likely it is caused by the low-density extrusive rhyolite (Carter and Cook, 1978).

Figure 9 shows a total magnetic intensity residual anomaly map. The broad northward trending magnetic high, of about 250 gammas of average total relief, that extends through the central part of the map, corresponds with the Mineral Mountains granitic pluton. In the south-central part of the map, the striking constriction of the magnetic high anomaly corresponds with 1) a similar constriction of the exposed pluton as a consequence of the volcanic domes which intrude the pluton in the area, 2) a postulated east-west lineament in this area, and 3 ) the southern end of the pronounced geothermal gradient an oma $1 y$.

Near the northern edge of the map ( $F$ of Fig. 9) the striking east-west linear trend of the magnetic contours, with a large gradient, corresponds with the northern margin of the Mineral Mountains pluton and the Millard-Beaver County Line fault zone. The continuation of the lineament across Milford Valley indicates that high magnetic susceptibility material (probably granitic) may underlie the alluvium of Milford Valley. Also a magnetic low (G of Fig. 9) partly coincides with the Bearskin and Little Bearskin volcanic domes.

Figure 10 shows the terrain-corrected Bouguer gravity anomaly, and an interpretative geologic cross section along the east-west line $2.2 \mathrm{~N}$. The density contrast between the bedrock and alluvium is assumed to be $0.5 \mathrm{gm} / \mathrm{cc}$. Gravity data along line $2.2 \mathrm{~N}$ indicates: 1) the north-trending Opal Mound horst, bounded on the east by the Opal Mound Fault with an indicated vertical 


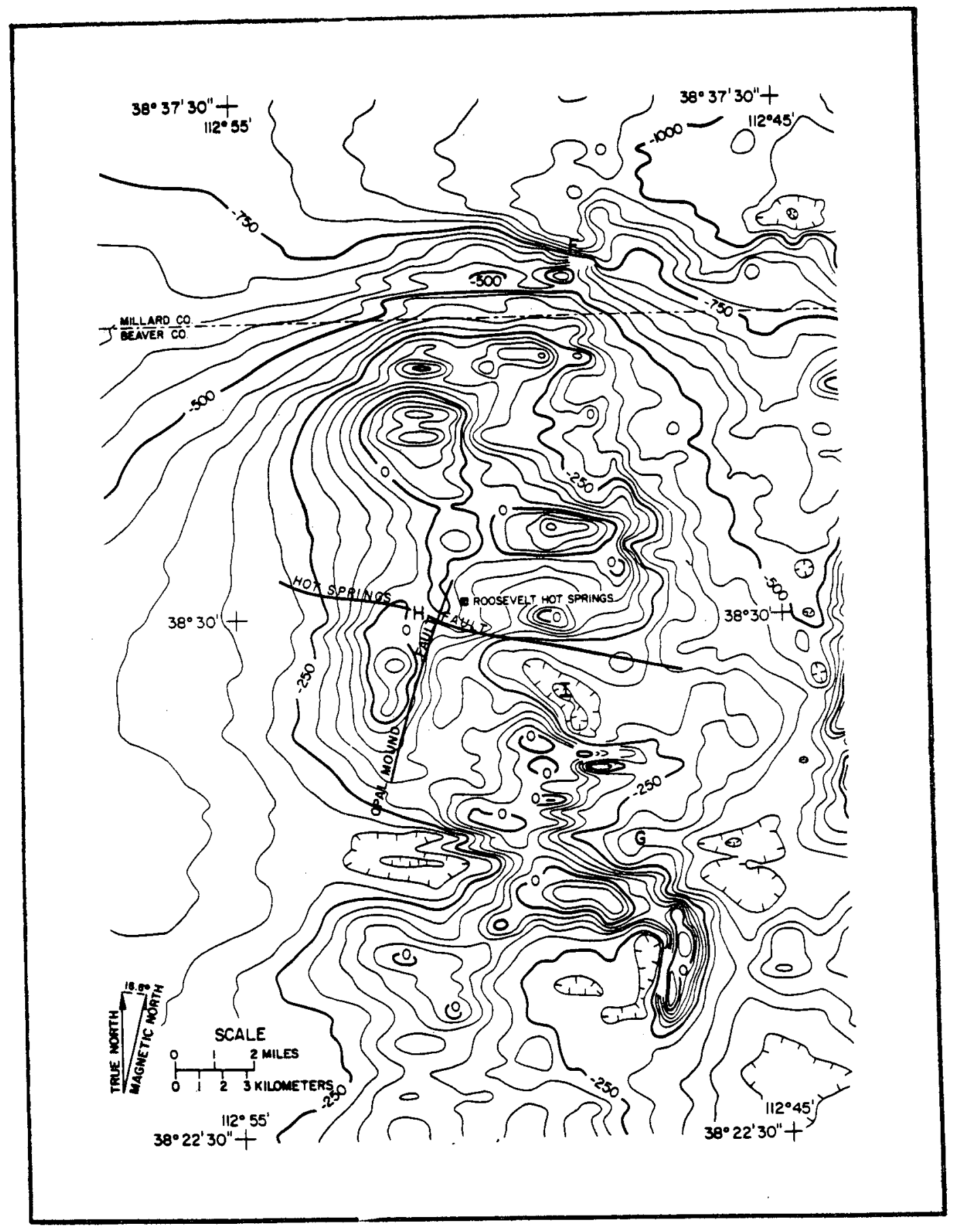

Fig. 9. Total aeromagnetic intensity residual anomaly map of the Roosevelt Hot Springs area. Contour interval $=50$ gammas. Data taken along east-west 1 ines at $1 / 4$ mile $(402 \mathrm{~m})$ spacing drape flown at an elevation of $1000 \mathrm{ft}(305 \mathrm{~m})$ above ground. Letter designations are described in text. After Ward and others, 1977. 


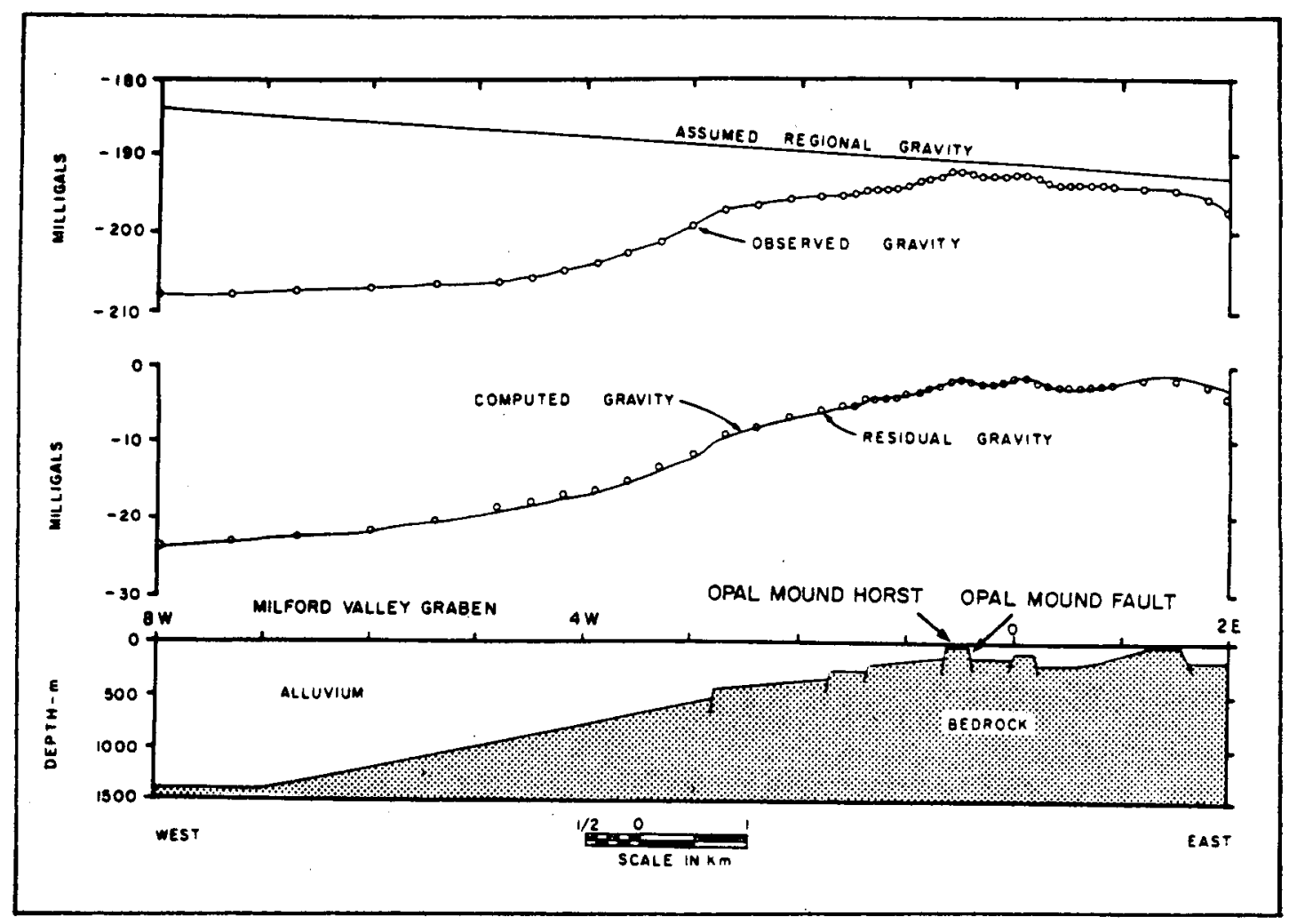

Fig. 10. Interpretative two-dimensional model for gravity profile along line 2.2N (see Fig. 9) of the Roosevelt Hot Springs area. Assumed density contrast is $0.5 \mathrm{gm} / \mathrm{cc}$. After Ward and others, 1977. 
displacement of about $50 \mathrm{~m}, 2$ ) step faults in the bedrock bounding the eastern margin of the Milford Valley graben, and 3) an alluvium thickness of about $1.4 \mathrm{~km}$ beneath Milford Valley at the western end of the profile. Gravity data indicates many pronounced faults striking both north-south and east-west in the Roosevelt Hot Springs thermal area.

As previously mentioned, Ward et al. (1977) assumed a density contrast of $0.5 \mathrm{~g} / \mathrm{cc}$ in their gravity modeling. Based on original gravity interpretations, it was predicted that the Acord 1-26 well in Milford Valley, SW $1 / 4$ of Sec. 26, T $26 \mathrm{~S}, \mathrm{R} 10 \mathrm{~W}$, would intercept high-density rock at 1.2-km depth (Group Seven, Inc., 1980). This high density, approximately $2.7 \mathrm{~g} / \mathrm{cc}$, was believed to be crystalline basement. However, on drilling it was found that the high-density rock consisted primarily of rhyolite tuff, to which 5-20 anhydrite had been added by deposition. This resulted in a density that was mistaken for that of granodiorite in the gravity interpretation.

Reinterpretation by Group Seven, Inc. of four gravity and magnetic profiles, which cross the Acord well site for control, has led to the assumption that the gravity surface, which is based on a marked increase in rock density, represents the surface of the rhyolite tuff and that the magnetic surface represents crystalline basement. Therefore, north of the Acord well in the area known as Beaver Bottoms, aeromagnetic data gives a depth to crystalline basement of at least 2.44 to $4.88 \mathrm{~km}$. Along east-west aeromagnetic profiles the magnetic basement lies $1525 \mathrm{~m}$ to slightly less than $305 \mathrm{~m}$ beneath the surface.

A contour map showing depth to crystalline basement is presented (Fig. 11) based on aeromagnetic data from these four profiles. Contour intervals of $1220 \mathrm{~m} \mathrm{(4000} \mathrm{ft)} \mathrm{are} \mathrm{used.} \mathrm{Unfortunately,} \mathrm{no} \mathrm{better} \mathrm{resolution}$ can be obtained, as depth correlation of the Acord well with the four profiles can differ by as much as $915 \mathrm{~m}$ (3000 ft) from site to adjacent site. However, a crude overview of the subsurface basement in Milford Valley can be obtained. Figure 11 shows a deepening of crystalline basement to the west of Roosevelt Hot Springs, with the Milford Valley axis oriented along a north trending line. Placement of a hinge in the axis in the vicinity of T27 S, $R$ $10 \mathrm{~W}$, shows a deepening of valley fill and depth to basement to the north and south. In the Beaver Bottoms area, north of the Acord well, there is a major downwarp (probably a separate fault block) giving a maximum depth to basement rock of $4.9 \mathrm{~km}$. This last configuration may be unrealistic because Geothermal 


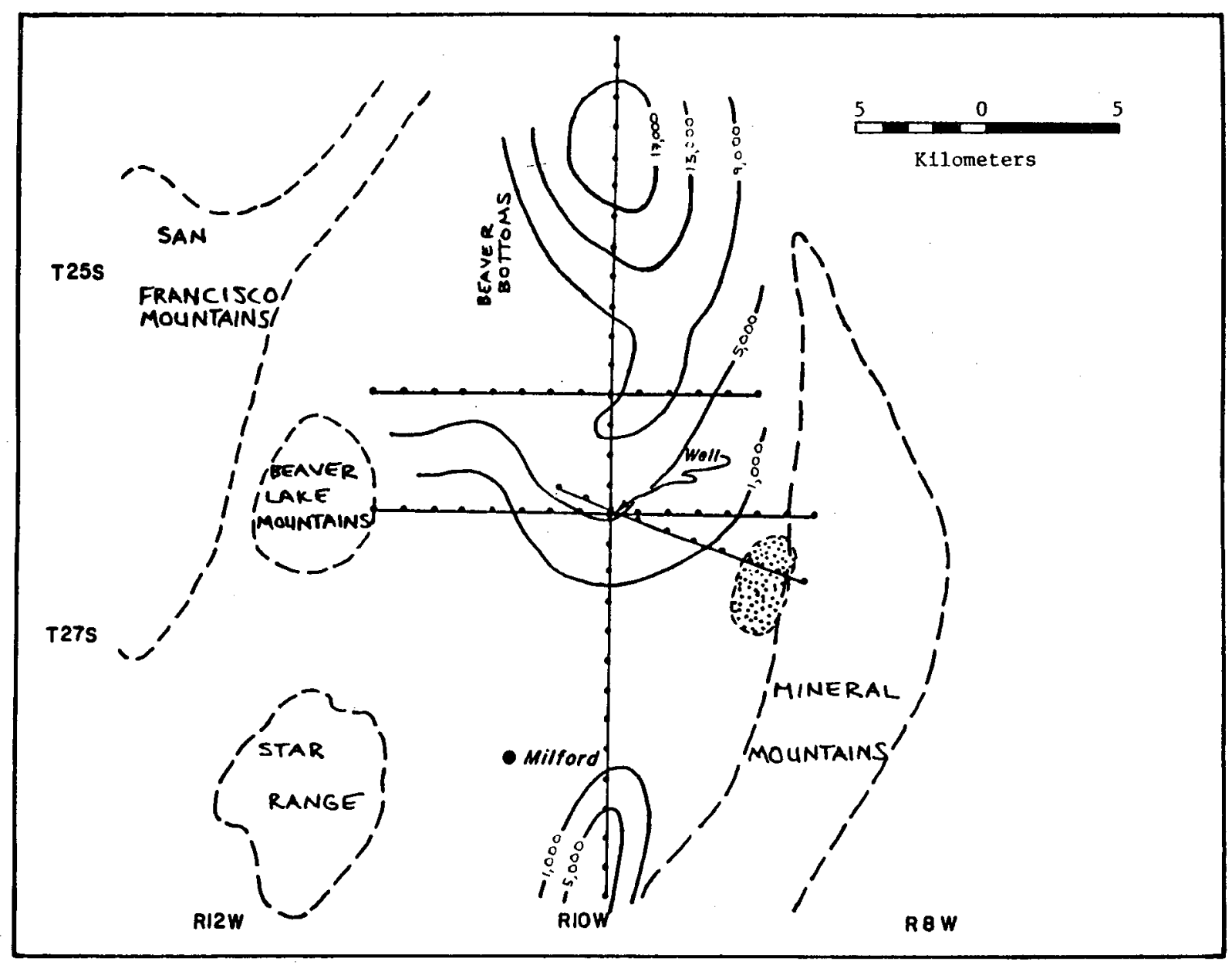

Fig. 11. Map of predicted depth to crystalline basement in Milford Valley, based on data from magnetic profiles. Contour interval $=4000 \mathrm{ft}(1220 \mathrm{~m})$. Stippled area shows approximate outline of the Roosevelt KGRA. "We11" means Acord 1-26 wel1. Modified after Group Seven, Inc., 1979. 
Kinetics, Inc. discovered a large magnetotulleric (MT) anomaly over the Beaver Bottoms area. The combined lack of magnetization and low resistivity in this small area could be due to temperature effects, or possibly, the presence of clays.

C. Thermal Measurements

Near-surface heat flow surveys by Sill and Bodell (1977) and Wilson and Chapman (1978) have proved useful in outlining the geometry of the hydrothermal system. Wilson and Chapman's contoured surface heat flow map of the Roosevelt area is based on 53 shallow thermal gradient holes (Fig. 12). The $100 \mathrm{~mW} / \mathrm{m}^{-2}$ contour outlines the limit of thermal effects associated with this geothermal system; anything less than $100 \mathrm{~mW} / \mathrm{m}^{-2}$ (2.4 HFU) is considered background Great Bas in heat flow for Utah. The $400 \mathrm{~mW} / \mathrm{m}^{-2}$ contours enclose an area of $57 \mathrm{~km}^{2}$, while the highest contour shown is $1000 \mathrm{~mW} / \mathrm{m}^{-2}$, which encloses an area of $16 \mathrm{~km}^{2}$, in particular a 2-km-wide band parallel to the Opal Mound Fault.

The pattern of the heat flow field is clearly controlled by geologic structure and indicates primarily convective heat flow associated with the hydrothermal system. The elongated heat flow high is parallel to and encloses the Opal Mound Fault. This zone has an abrupt southern termination by a set of west by northwest trending faults and changes trend at the intersection of the Opal Mound and Negro Mag faults. Heat flow contours in many parts of the field parallel mapped or inferred faults. The re-emergence of the $400 \mathrm{~mW} / \mathrm{m}^{-2}$ contour to the southwest of the area coincides with fault blocks inferred from gravity and electrical resistivity studies (Ward and Si11, 1976) and may result from water leakage over an impermeable upthrown block (Wilson and Chap$\operatorname{man}, 1978$ ).

Thermal gradients and heat flow measurements for deep dry holes will be discussed in Sec. V. E., "Hot Dry Wells."

\section{Electrical Measurements}

Most of this section is taken from summary work by Ward and others (1977) and work by Group Seven, Inc. for Geothermal Kinetics, Inc. Electrical surveys performed at Roosevelt Hot Springs thermal area include $100 \mathrm{~m}, 300 \mathrm{~m}$, and $1 \mathrm{~km}$ dipole-dipole resistivity, Schlumberger resistivity soundings, electromagnetic soundings, and magnetotelluric soundings. Figure 13 portrays the 


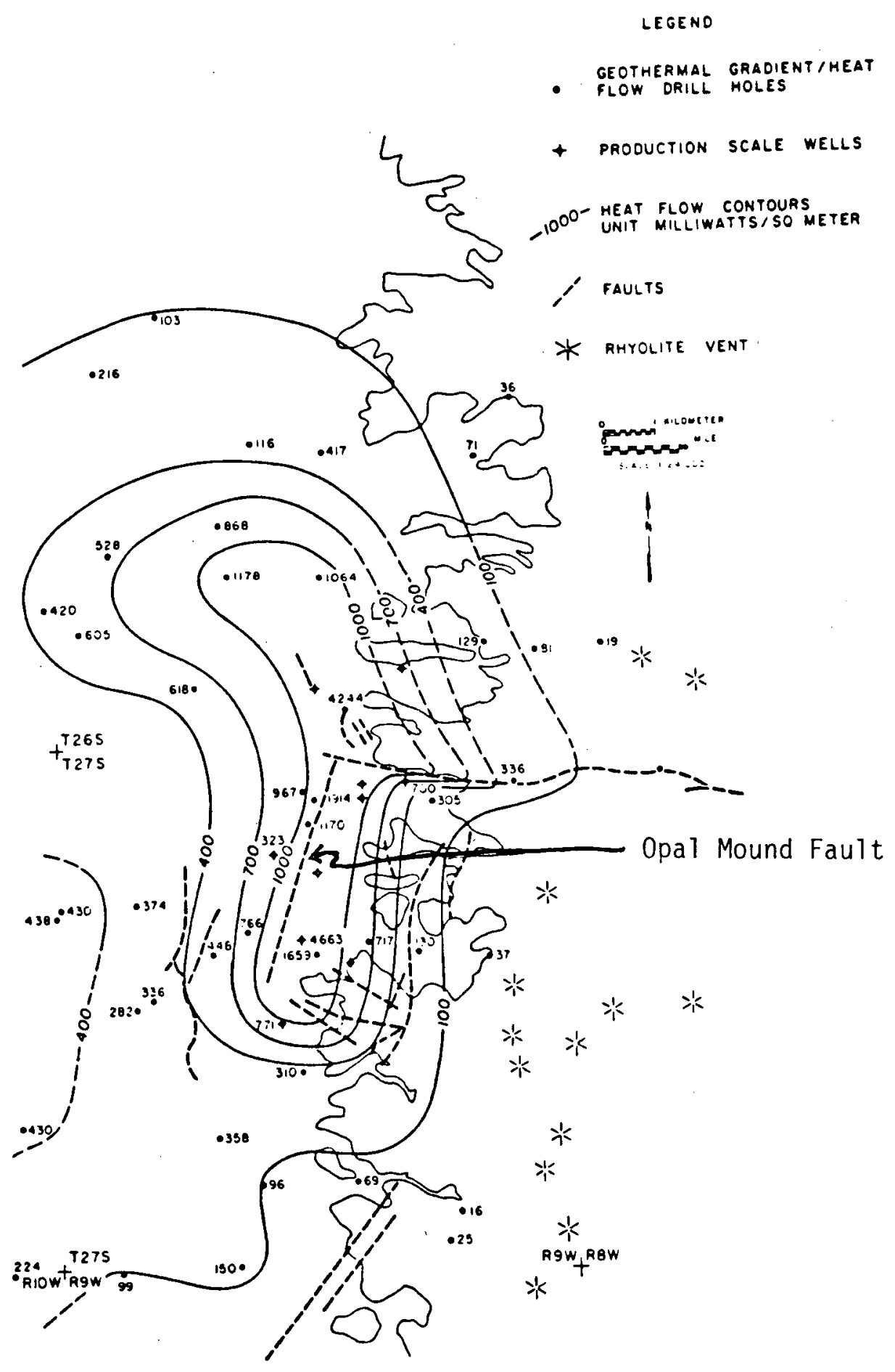

Fig. 12. Surface heat flow pattern at the Roosevelt Hot Springs, based on $53 \mathrm{dpill}$ holes. After Wilson and Chapman, 1978. 


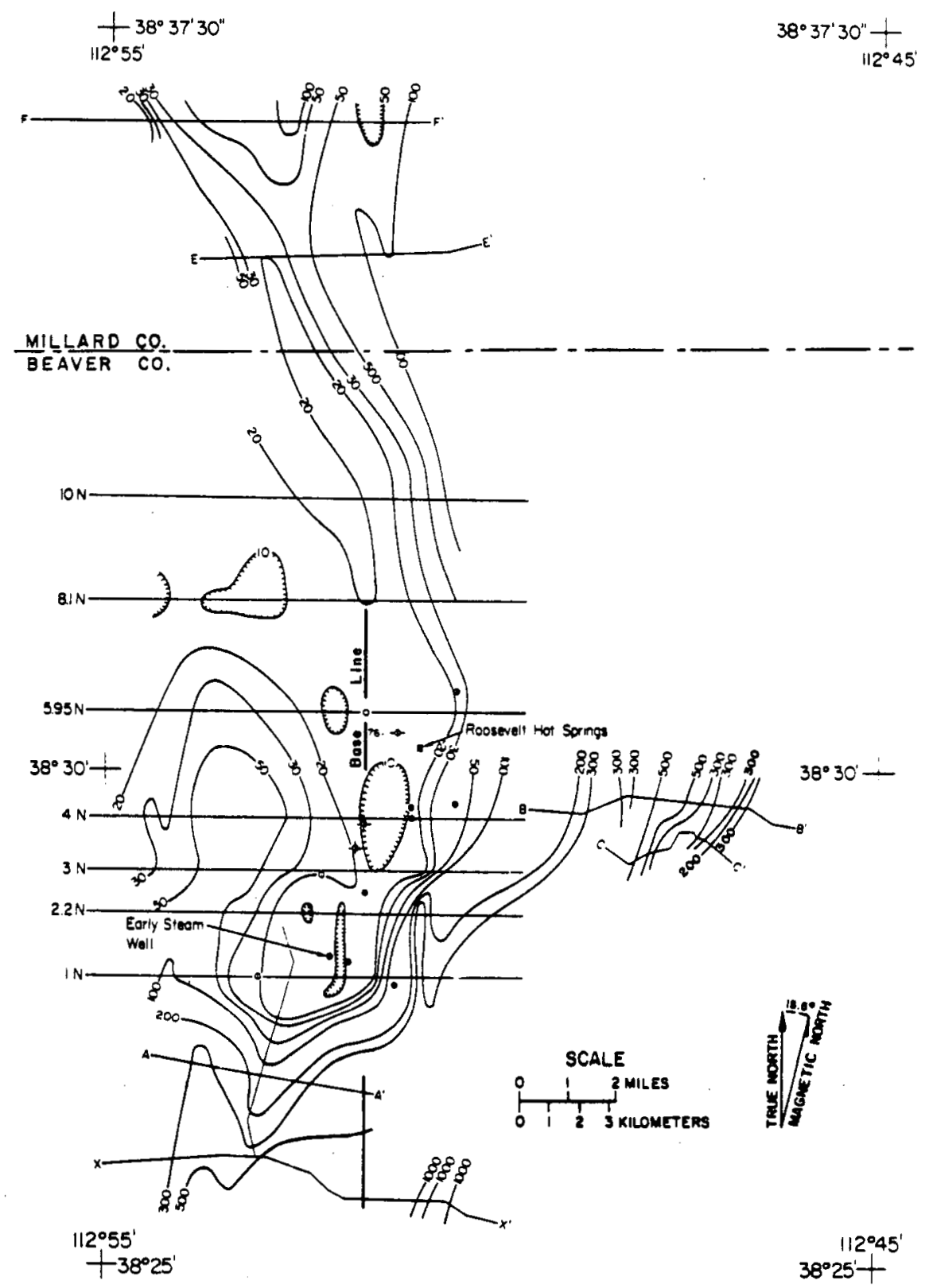

Fig. 13. Contours of apparent resistivity obtained with diopledipole array, first separation, over the Roosevelt Hot Springs area. Contours at 10, 20,30, 50, 100 ohm-m and multiples of ten times these figures. Productive wells shown by solid dots, "dry wells" by open circles, shallow al teration holes by circles with crosses. Traverse lines are shown. After Ward and others, 1977. 
contours of apparent resistivity observed over the geothermal field in first separation $300 \mathrm{~m}$ dipole-dipole resistivity surveying. It is believed to demonstrate the distribution of brine-soaked clays in the top $500 \mathrm{~m}$ of the system. The clays are alteration products of feldspars and occur dominantly along faults and fractures in the Tertiary granitic host rock. Because clay alteration is prevalent along fractures, the $100 \mathrm{~m}$ dipole-dipole survey delineated major fractures in the geothermal field.

When all of the data from active electrical methods is combined, the pseudo-geological model of Fig. 14 is generated (Ward and others, 1977). This is the best model to depths of $500 \mathrm{~m}$ for 1 ine $3.5 \mathrm{~N}$ of Fig. 13, beyond which the active electrical methods totally lacked resolution.

The apparent resistivities from 25 MT soundings have been inverted to one-dimensional model earths at each sounding site. The resulting model is believed to be a totally unrealistic representation of a subsurface distribution of true resistivities while simultaneously being diagnostic of a convective hydrothermal system. The observed resistivities of less than 1 ohm-m at depths of order 2 to $3 \mathrm{~km}$ are virtually impossible to obtain unless graphitic horizons or massive sulfides are present; clay alteration should be absent at these depths. Current geologic evidence precludes these possibilities. Ward and others (1977) believe that the subsurface resistivities interpreted from the MT data are artifacts of the interpretation technique.

Geothermal Kinetics, Inc. $r$ an two MT surveys in the Milford Valley area. The earlier survey showed an anomaly in the Beaver Bottoms area, later substantiated by a 1979 survey. Surface electrical surveys over this MT anomaly showed a relatively shallow conductive zone, whereas a large mass of rock at depth shows a low resistivity and is nonmagnetic. Group Seven, Inc. proposed that this large mass of rock may be the intruded hot rock mass which is the heat source for Roosevelt Hot Springs.

\section{v. ROOSEVELT GEOTHERMAL FIELD}

\section{A. Drill History}

Dr. Eugene Davies of Milford initiated geothermal exploration in 1968 . He drilled on the east flank of the Opal Mound with a steam blowout at $82 \mathrm{~m}$. Phillips Petroleum won most of the surrounding leases in the July 1974 KGRA sale, and drilled six wells in 1975. The first deep well was unsuccessful, 


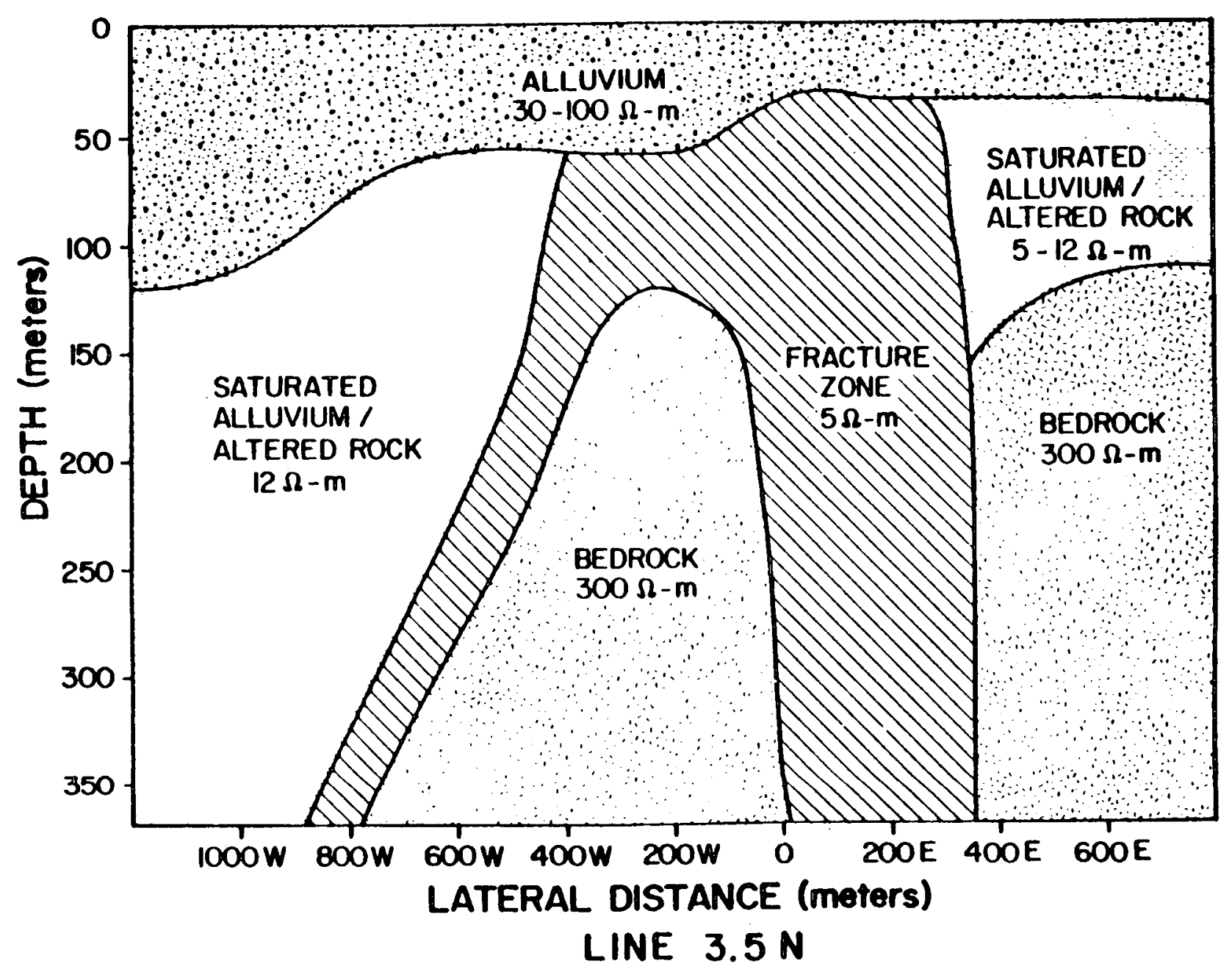

Fig. 14. Pseudo-geologic interpretation of geoelectric section obtained from several electrical surveys along traverse $3.5 \mathrm{~N}$ (see Fig. 13 for coordinate location) of the Roosevelt Hot Springs area. After Ward and others, 1977. 
with low levels of fluid production at depth of $2099 \mathrm{~m}$. The others were all productive, ranging in depth from 830 to $2230 \mathrm{~m}$. Bottom-hole temperatures were about $260^{\circ} \mathrm{C}$. Other lease holders now include Geothermal Power Corporation, Getty $0 i 1$ Corporation, Thermal Power Company and 0'Brien Resources Inc., Geothermal Exploration Company, American Geological Enterprises, and Union $0 i 1$.

Seven producing wells have been completed (Fig. 15). They cover a $6-\mathrm{km}^{2}$ area and range in depth from 382 to $2234 \mathrm{~m}$. Ward and others (1978) indicate the average well has a potential fluid production of $4.5 \times 10^{5}$ $\mathrm{Kg} / \mathrm{h}$ at shut-in bottom-hole temperatures of around $260^{\circ} \mathrm{C}$. Utilization of the energy at Roosevelt is dependent on present dealings with Utah Power and Light (UP and L). It is hoped an initial 20-MWe power plant and two 55-MWe plants will be on line by 1982 . The initial agreement between UP and $L$ and Phillips was finalized in late 1981 .

B. Hydrothermal Al teration

All rocks have been weakly to strongly altered in the Roosevelt Hot Springs area. Acid-sulphate water altered rocks to alunite and opal at the surface, and to kaolinite, alunite, montmorillonite and muscovite to a depth of $50 \mathrm{~m}$. Deeper alteration by chloride-rich waters formed muscovite, chlorite, calcite, K-feldspar, albite and epidote (Parry and others, 1978). Alteration is most intense at or near the surface near the Opal Mound Fault, and is less intense in deeper wells, and in wells more remote from the fault. Fracture zones and some dikes also show hydrothermal alteration.

Silica-cemented alluvium is localized along the Opal Mound Fault. Alluvium in general shows a high degree of calcite cementation (Hulen, 1978). This calcite-cemented alluvium may serve as a caprock for the geothermal reservoir, preventing heat and fluid loss.

\section{Water Chemistry}

The Roosevelt Hot Springs are located along the Opal Mound Fault near its juncture with the Negro Mag Fault. The springs discharged during historic times but flow appears to have ceased about 1963 (Petersen, 1975). W. T. Lee in 1908 stated that one spring flowed at a rate of $10 \mathrm{gpm}$ and that the temperature was at least $87^{\circ} \mathrm{C}$. Mundorff (1970) states that the main spring was dry in 1966 and records water temperatures from seeps of 82 and $54^{\circ} \mathrm{C}$. 


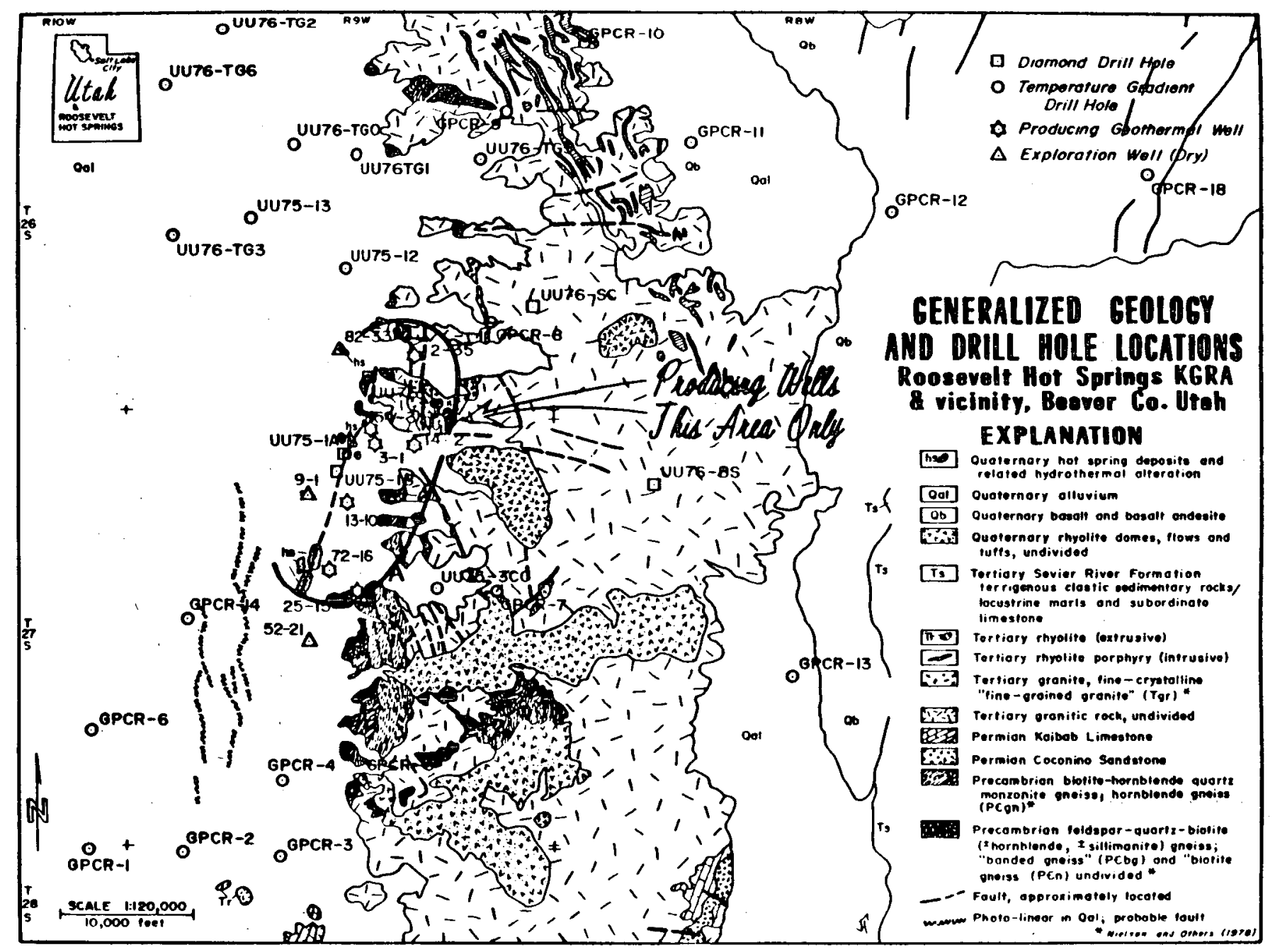

Fig. 15. Well C/T-2 is shown here as exploration well 9-1. After Bamford and others, 1980. 
Swanberg (1974) gives a Na-K-Ca geothermometer estimate of $289^{\circ} \mathrm{C}$ for the Roosevelt Hot Springs, the highest rating of a thermal water in the state of Utah. Calculation of sulfate geothermometers for the Roosevelt area by Nehring and others (1979) gives average temperatures of approximately $275^{\circ} \mathrm{C}$ for three deep wells, $145^{\circ} \mathrm{C}$ for one shallow we11, and $216^{\circ} \mathrm{C}$ for the Roosevelt seep. Soil temperatures of 95 to $97^{\circ} \mathrm{C}$ have been measured at depths of 1 to $3 \mathrm{~m}$.

Surface and deep thermal waters are dilute (ionic strength $=0.1$ ) sodium chloride brines; average chloride $\sim 3700 \mathrm{mg} / \ell$ (Parry and others, 1978). The water from Roosevelt Hot Springs also contains high silica content.

D. Hydrothermal Reservoir

In order to determine the feasibility of Hot Dry Rock geothermal exploration at Roosevelt Hot Springs, the hydrologic cycle and its relationship to the hydrothermal reservoir must first be understood. It is believed that water circulates at depth along mainly north-south trending

- normal faults that border the western edge of the range. Water recharge may also occur along high-angle east-west faults. The water is heated at depth and then rises along high-angle faults in the geothermal area until it reaches low-angle fault planes associated with the gravity slide blocks. The low-angle faults allow fluids to migrate subhorizontally along the plate. These upper plates have been highly faulted and mylonitized, creating a permeable zone ideal for the circulation of hot water.

Because the hydrothermal area is structurally controlled, this gives the field rather distinct boundaries. The north-south trending Opal Mound Fault bounds the field on the west, whereas the Mineral Range bounds it on the east. However, to the north and south, the edges of the field are more difficult to delineate. Producing wells have been drilled north of the eastwest trending Negro Mag Fault and the northern boundary may extend to the Salt Cove area, but the controlling structures are not fully understood. To the south, a major structural zone, interpreted as a series of intersecting faults, has been identified from a combination of electrical resistivity and radon emanometry studies (Nielson, 1978). This feature is situated between Utah State well 72-16 (productive) and 52-21 (non-productive) and may terminate the hydrogeothermal field to the south. Thus, the present day geothermal field at Roosevelt has an areal extent of about $20 \mathrm{~km}^{2}$. 
Wilson and Chapman (1979) delineated a water circulation pattern based on heat flow and thermal gradient determinations for 53 shallow drill sites in the vicinity of Roosevelt Hot Springs. They recognized three spatially consistent patterns indicative of heat-transfer processes associated with the geothermal system. Three distinct temperature groups, labeled I, II, and III, represent hydrologic recharge, active convection, and discharge regions, respectively (Fig. 16).

Group I sites along the east and west flanks of the Mineral Mountains pluton are characterized by low-thermal gradients due to hydrologic recharge. That the Mineral Mountains are the probable source region for water in the system is substantiated by oxygen isotope studies by Bowman (1979). Group II sites located west of and parallel to the Mineral Mountains exhibit very high shallow gradients (up to $331^{\circ} \mathrm{C} / \mathrm{km}$ ), due to their close proximity to the geothermal reservoir. Group III sites, further west on the floor of Milford Valley, possess near-surface gradients intermediate between groups I and II. Wilson and Chapman suggest that such gradients of about 7 times background encountered up to $6-\mathrm{km}$ west of thé Opal Mound Fault, require either multiple or broad heat sources or, al ternatively, lateral mass and heat transport westward across Milford Valley.

E. Hot Dry Wel1s

As Wilson and Chapman's studies demonstrated, an understanding of the hydrology of the Roosevelt geothermal system is greatly aided by available well hole data. However, for the purposes of HDR exploration, deep holes that give "true" thermal gradient and heat flow are more desirable. Unfortunately, most of the available data were gathered from shallow drill holes or holes that are otherwise hydrothermally disturbed. Most temperature data on deep dry holes are proprietary, even though they are non-productive. Hot dry well temperature information to date is restricted to three wells; Los Alamos National Laboratory $\mathrm{C} / \mathrm{T}-2$. (originally Phillips 9-1), Utah State 52-21 (originally Getty 0i1 52-21), and Acord 1-26, a partnership drill effort involving Geothermal Kinetics, Inc., McCulloch, and others.

Phillips 9-1 is located in the north-central part of Sec. 9, T 27 S, R 9 $W$, about $0.5 \mathrm{~km}$ west of the Opal Mound Fault. The well is set aside for use by Los Alamos National Laboratory for the testing and calibration of drilling tools. The Earth Science Laboratory/University of Utah Research Institute has 


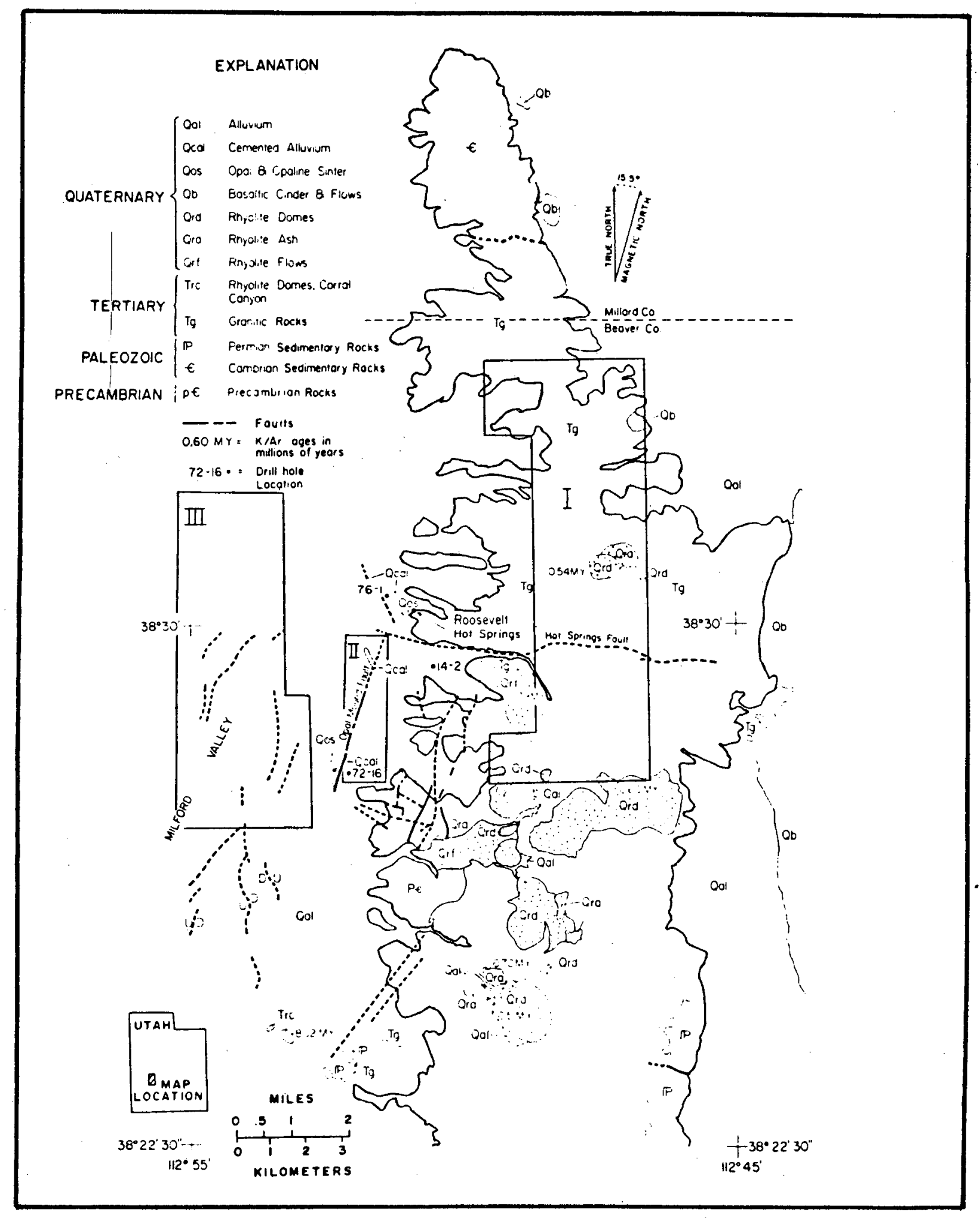

Fig. 16. Location of three areas in the Roosevelt Hot Springs which exhibit differing temperature-depth behaviors. After Wils on and Chapman, 1978. 
completed a comprehensive study of Phillips 9-1 cuttings and well logs for the Los Alamos National Laboratory. The well intersects Precambian banded gneiss and several phases of the Mineral Mountains pluton, and bottoms in Tertiary diorite (Fig. 17). Total depth of the well is $2099 \mathrm{~m}$. The bottom-hole temperature is $228^{\circ} \mathrm{C}$. Calculation of the thermal gradient for the 1 ower $1000 \mathrm{~m}$ of 9-1 gives a value of $56^{\circ} \mathrm{C} / \mathrm{km}$ (Fig. 18).

Getty 0i1 52-21 was sponsored by DOE's Industry Coupled Program. Nielson and others (1978) present a detailed lithologic log of the well, while Glen and Hulen (1979) give an evaluation of the geophysical 1ogs. The well is located beyond the southern end of the Roosevelt geothermal field, and is $2281 \mathrm{~m}$ in depth. The lower section of the hole is in crudely to moderately foliated banded gneiss, which is intruded by granodiorite gneiss and quartz monzonite. Temperature logs indicate $202^{\circ} \mathrm{C}$ at a depth of $2242 \mathrm{~m}$, with a temperature gradient over the 305 to $2242 \mathrm{~m}$ interval of $58^{\circ} \mathrm{C} / \mathrm{km}$.

The Acord 1-26 well, in the SW 1/4 of Sec. 26, T $26 \mathrm{~S}, \mathrm{R} 10 \mathrm{~W}$, is in Milford Valley, approximately $8.5 \mathrm{~km}$ west-northwest of the Roosevelt geothermal field. The well was drilled to a depth of $3855 \mathrm{~m}$, where a bottom-hole temperature of about $230^{\circ} \mathrm{C}$ is recorded. A7though temperature logs are not available, this figure gives an average gradient over the entire hole of $60^{\circ} \mathrm{C} / \mathrm{km}$, well with in the parameters of HDR geothermal production. According to a study performed by Group Seven, Inc., the heat flow in Acord 1-26 is approximately $146 \mathrm{~mW} / \mathrm{m}^{2}$, sufficiently high to indicate that there may be a shallow heat source in the crust below the well.

Lake sediments are found in the upper $976 \mathrm{~m}$ of the Acord 1-26 we11. They are underlain by sandstone and conglomerate. Also within this section is a 24-m interval of dacite and rhyolite at $2156 \mathrm{~m}$. From $3172 \mathrm{~m}$ to the bottom, the well is in quartz monzonite. Acord 1-26 was drilled in the spring of 1979 to investigate a resistivity low discovered during a magnetotelluric survey. Inspection of temperature, caliper, gamma-ray neutron, and dual-channel density logs, supplemented by an increased drilling rate between 3507 to $3812 \mathrm{~m}$, indicated the presence of a fracture zone over this depth interval. Casing was set to $3507 \mathrm{~m}$, yet after testing the well for fluid production, it became clear that there was no permeability from $3507 \mathrm{~m}$ to the bottom of the well. The combination of high temperature and low permeability in crystalline rocks makes the Acord 1-26 a good candidate for HDR geothermal production. 


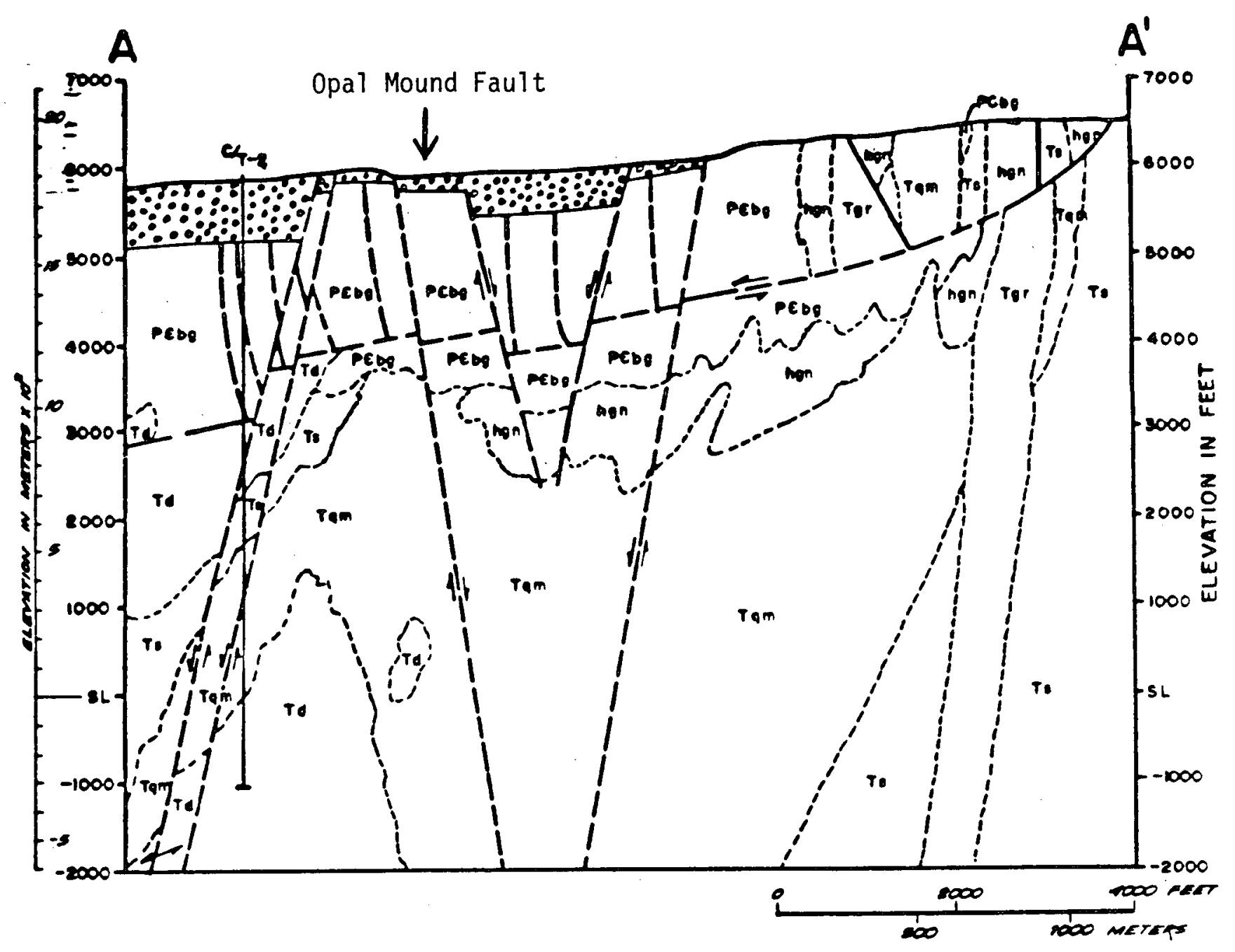

Fig. 17. Geologic cross section of the Roosevelt Hot Springs geothermal area showing well C/T-2. After Glenn and others, 1980. 


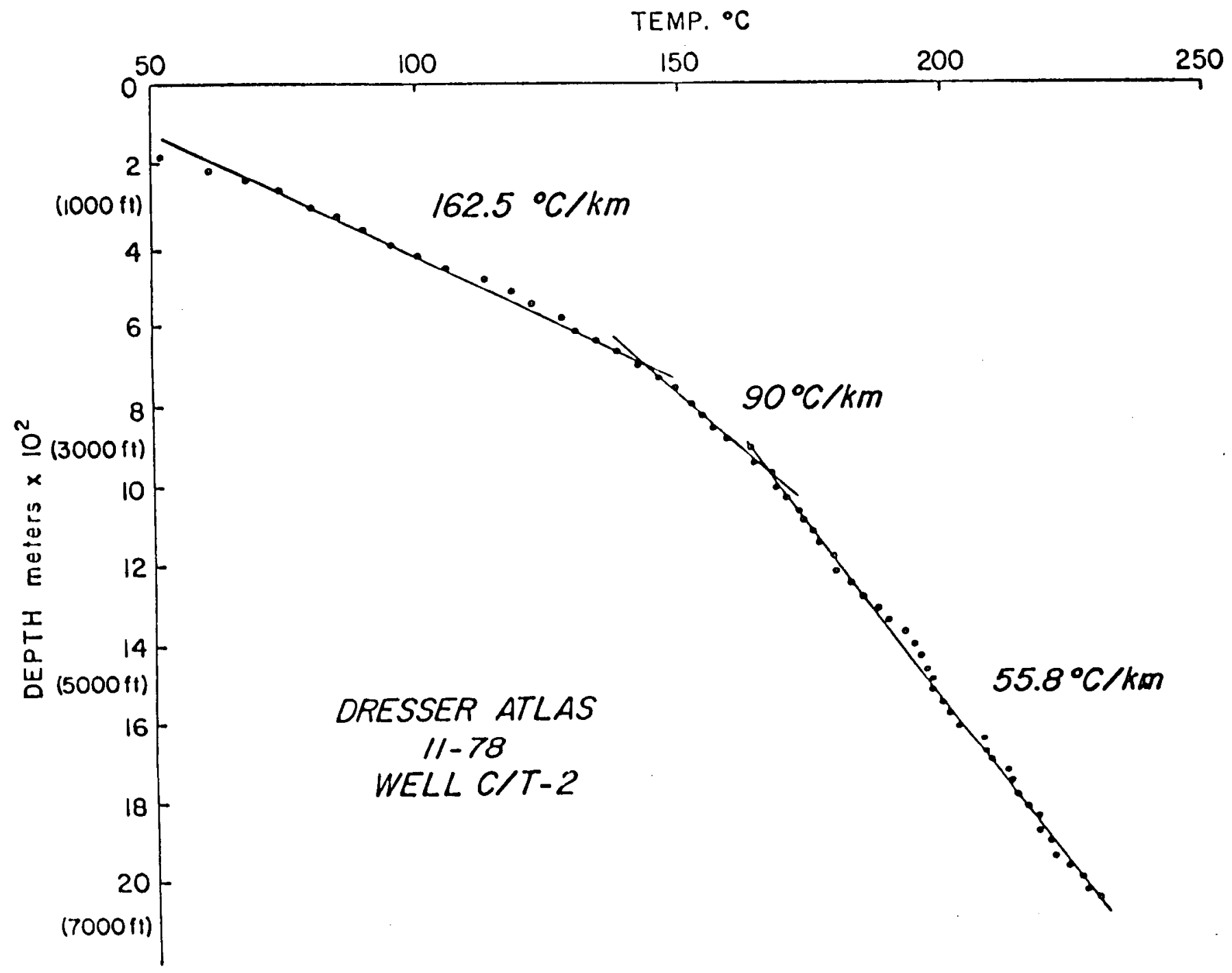

Fig. 18. Temperature vs depth $10 \mathrm{~g}$ of Dresser Atlas 11-78 wel1 C/T-2. 
Two additional deep dry wells are located outside the Roosevelt geothermal field and have helped to delineate the reservoir's boundaries. However, no temperature data or other information except of a general nature is now available. These wells are Phillips 42-9 and Phillips 82-33.

The Phillips 42-9 well was Phillips first exploration well, drilled in 1975 and it extends $2100 \mathrm{~m}$. Temperature and lithology of the well is not available. Phillips $82-33$ is located in the NE $1 / 4$ of Section 33 , off the northwest end of the KGRA. The well is situated on hot spring deposits of silica-cemented alluvium. Temperature, lithology, and depth of the well are not available.

F. HDR Reservoir Rock at Mineral Mountain

Tertiary granitic rocks of the Mineral Mountains pluton east of Roosevelt Hot Springs appear to be the best target for a HDR geothermal reservoir. The rock is generally medium- to coarse-grained and does not show extensive hydrothermal alteration, except where adjacent to major high-angle faults or within the existing geothermal field at shallow depths. Gneissic rock, on the other hand, is often foliated so that control over fracturing may be more difficult.

The Mineral Mountains pluton is bounded on the south by the Cave Canyon Fault and on the north by the County Line Fault-Black Rock Offset. The northern and southern limits of the Tertiary intrusive are substantiated by gravity and magentic work, which exhibit east-west trending contours of large relief corresponding with the above two faults (Carter and Cook, 1978). The Black Rock Offset is a major structure and represents the northern boundary of Tertiary intrusive activity in west-central Utah. Carter and Cook (1978) state that Tertiary intrusive rock may underlie most of Milford Valley. The Acord 1-26 we11, in the middle of the valley supports this statement, with a lower 683-m section of quartz monzonite from 3172 to $3855 \mathrm{~m}$. Based on aeromagnetic studies by Geothermal Kinetics, Inc., this author has contoured approximate depths to the crystalline basement (HDR reservoir rock) in Milford valley (Fig. 11).

VI. CONCLUSION

In conclusion, many of the criteria that support a potential HDR site are met at Roosevelt Hot Springs. Regionally, the area is part of the Basin 
and Range-Colorado Plateau transition, characterized by extensional tectonics and high heat flow. Locally, the Roosevelt Hot Springs area has undergone young ( 0.5 to $0.8 \mathrm{Myr})$ silicic volcanism. Moreover, extensive basalt fields as young as 10000 years occur to the north and east. Recent volcanism and possibly uncrystallized source magma is believed to be the heat source for the Roosevelt Hot Springs area.

Because of the promise of hydrogeothermal production at Roosevelt, extensive work was done in order to determine the dimensions and structural control of the geothermal reservoir and the distribution of shallow heat flow and hydrologic patterns, as well as the subsurface structure and bedrock configuration. Although no magma reservoirs have been conclusively found, seismic and magnetotelluric surveys in the Roosevelt area have picked up major anomalies suggestive of partially molten or plastic material at depth.

The KGRA contains seven geothermal wells, with an initial producing capability of 130 MWe. In addition, several hot dry wells have been drilled on the periphery of the KGRA and out on the floor of Milford Valley. Although scant information on these holes is available, it is known that two of the wells have bottom-hole temperatures of about $230^{\circ} \mathrm{C}$ and high gradients of approximately $55-60^{\circ} \mathrm{C} / \mathrm{km}$.

The areal dimensions of the Roosevelt Hot Springs area thermal anomaly are not yet well defined. However, it seems most likely that the thermal anomaly falls within the area bounded by the County Line Fault on the north, the eastern portion of the Milford Valley on the west, and the Mineral Range on the east. It has not yet been determined whether a thermal anomaly exists beneath the eastern side of the Mineral Range. The southern extent of the thermal anomaly is much more difficult to determine; it is at least as far south as the hot dry Getty 011 Co. well 52-21. The anomaly may very likely extend as far as the Ranch Canyon area, which marks the southernmost exposure of Quaternary rhyolite.

Based on the available, if somewhat spotty, data the thermal anomaly present in the Mineral Mountains-Milford Valley area has been calculated to cover between 160 to $475 \mathrm{~km}^{2}$. Location of thermal anomaly boundaries for the maximum and minimum figures given is shown in Fig. 19. The minimum figure of $160 \mathrm{~km}^{2}$ is a fairly conservative estimate based on the northern, southern, and westernmost limits of hot dry wells, and on anomalies within the western flank of the Mineral Range. The maximum figure of $475 \mathrm{~km}^{2}$ is 


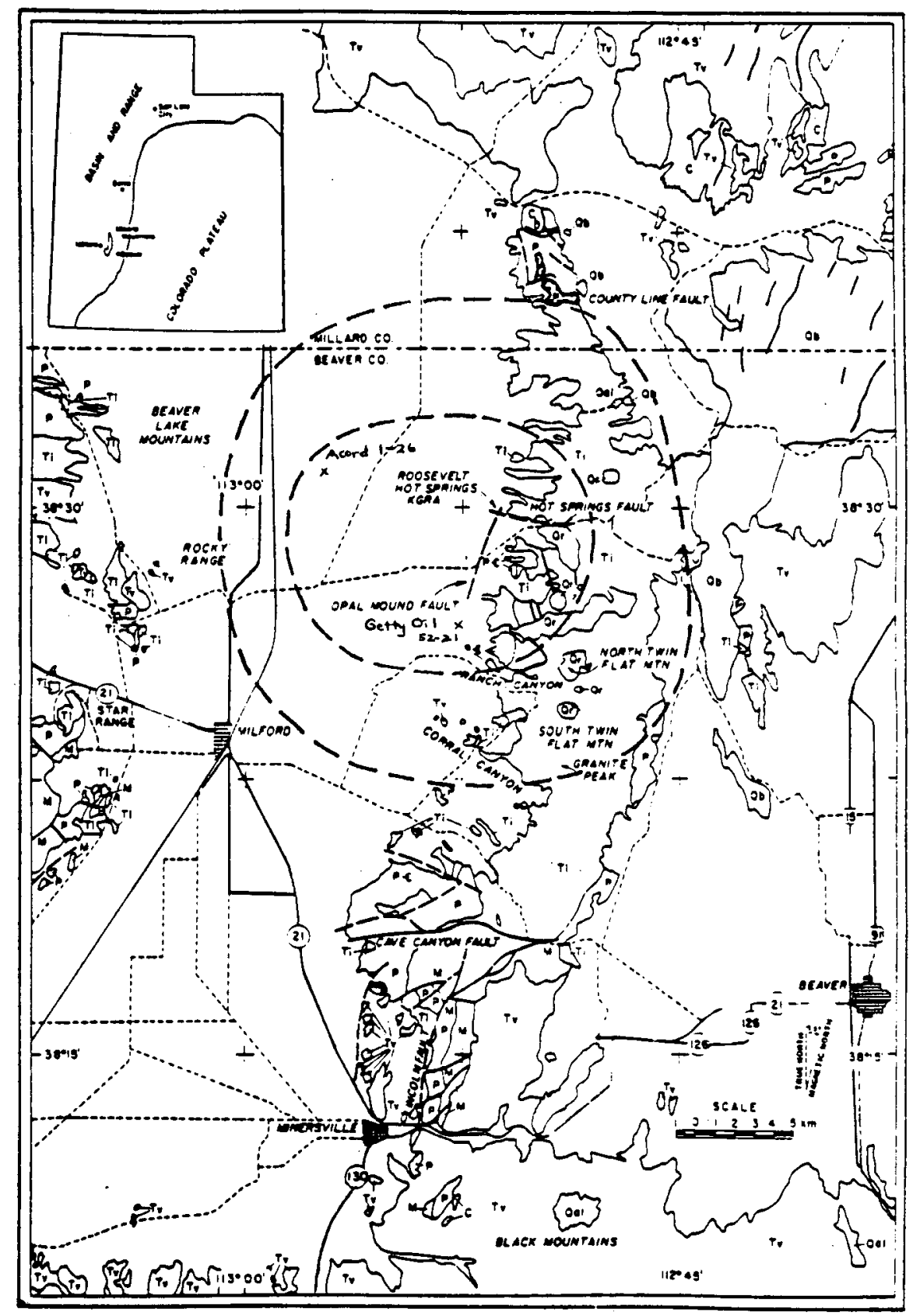

Fig. 19. Approximate areal extent of the thermal anomaly present at the Roosevelt Hot Springs area, showing proposed upper and lower limits. The most conservative estimate is represented by the inner circle enclosing $160 \mathrm{~km}^{2}$, while the outer circle encloses an area of $475 \mathrm{~km}^{2}$. Modified after Yusas and Bruhn, 1979. 
partially based on rather arbitrary southern and western boundaries beyond the hot dry wells. The eastern limit is placed along the east edge of the Mineral Mountains, and the north limit is the County Line Fault-Black Rock Offset. Within this high thermal-anomaly area the Roosevelt Hot Springs KGRA possesses an areal extent of $20 \mathrm{~km}^{2}$ or less. This is significant in that less than 12.5 of the thermal anomaly may be hydrothermal, while the remaining represents area potentially favorable for hot dry rock geothermal exploration.

\section{RECOMMENDATIONS}

If interested in a HDR site at Roosevelt Hot Springs, the Los Alamos National Laboratory should first take advantage of pre-existing hot dry wells that are peripheral to the hydrothemal field or further west within Milford Valley. At least two of these wells have the proper temperature and reservoir rock type (Tertiary plutonic rock). Drilling of an accessory shallower hole nearby and hydrofracturing will be necessary before further deepening and commercialization.

On the other hand, if the Los Alamos National Laboratory is unable to obtain one of the hot dry wells, the presence of an overall high heat flow in the Roosevelt area facilitates the location of a suitable HDR site. Two obvious factors should be kept in mind. The first is to locate an area where basement is not at an unreasonable depth. The Tertiary granitic intrusive rocks, the most suitable reservoir rock type, apparently form a major portion of the valley floor. However, not enough deep drilling has been done to substantiate this, whereas magnetic and gravity work is unable to distinguish Precambrian gneiss from Tertiary granitic rock. The second factor in locating a HDR geothermal well is detection of the high-angle Basin and Range faults which successively step down into the Milford Valley. To keep a tight control on fluid circulation, a fault zone should of course be avoided.

Location of depth to basement can be aided by further seismic, magnetic and gravity work, while resistivity and soil mercury surveys could possibly help in delineating major faults. 


\section{ACKNOWLEDGMENTS}

This effort was supported by Dennis Nielson at the University of Utah Research Institute and A. J. Aldrich and A. W. Laughlin of the Los Alamos National Laboratory. Aaron $C$. Waters kindly reviewed and improved the manuscript. Fraser Goff and Grant Heiken, at the Los Alamos National Laboratory, provided much encouragement and advice.

\section{REFERENCES}

Armstrong, R. L., 1970, Geochronology of Tertiary igneous rocks, eastern Bas in and Range Province, western Utah, eastern Nevada, and vicinity, USA: Geochimica et Cosmochimica Acta, v. 34, pp. 203-232.

Armstrong, R. L., 1972, Low-angle (denudation) faults, hinterland of the Sevier Orogenic Belt, eastern Nevada and western Utah: Geol. Soc. America Bul1., v. 83, pp. 1729-1754.

Bamford, R. W., 0. D. Christiansen, and R. M. Capuano, 1980, Multielement geochemistry of solid materials in geothermal systems and its applications Part 1: The hot-water system at the Roosevelt Hot Springs KGRA, Utah: Univ. Utah Res. Inst., Earth Science Laboratory, DOE/DGE contract DE-AC03-79ET-27002, 168 p.

Bowman, J. R., 1979, Stable isotope investigation of fluids and water-rock interaction in the Roosevelt Hot Springs thermal area, Utah: Univ. Utah, Dept. of Geology and Geophysics, DOE/DGE topical report, contract EY-76-S-07-1601, v. $77-10$.

Buddington, A. F., and D. H. Lindsley, 1964, Iron-titanium oxide minerals and synthetic equivalents: Jour. Petrology, v. 5, pp. 310-357.

Carter, J. A., and K. L. Cook, 1978, Regional gravity and aeromagnetic surveys of the Mineral Mountains and vicinity, Millard and Beaver Counties, Utah: Univ. Utah, Dept. of Geology and Geophysics, DOE/DGE final contract EY-76-S-07-1601, v. 77-11, 178 p.

Chapman, D. S., D. D. Blackwell, W. T. Parry, W. R. Sill, S. H. Ward, and S. H. Whelan, 1978, Regional heat flow and geochemical studies in southwestern Utah: Univ. Utah, Dept. of Geology and Geophysics, U.S. Geol. Survey contract 14-08-0001-G-341, $115 \mathrm{p}$.

Christiansen, R. L., and P. W. Lipman, 1972, Late Cenozoic, Pt. 2 of Cenozoic volcanism and plate-tectonic evolution of the western United States: Royal Soc. London Philos. Trans., ser. A., v. 271, pp. 249-284.

Condie, K. C., and C. K. Barsky, 1972, Origin of the Quaternary basalts from the Black Rock Desert region, Utah: Geol. Soc. America Bull., v. 83, pp. 333-352. 
Cook, K. L., J. R. Montgomery, J. T. Smith, and D. C. Selk, 1975, Gravity gradients across the Wasatch Line: Geol. Soc. America Abst. with Progs., v. $7, \mathrm{n} .7, \mathrm{p} .1038$.

Crebs, T. J., and K. L. Cook, 1976, Gravity and ground magnetic surveys of the Central Mineral Mountains, Utah: NSF Final Report, Grant GI 43741, v. 6, $129 \mathrm{p}$.

Crosby, G. W., 1973, Regional structure in southwestern Utah, in Geology of the Milford area: Utah Geol. Assoc., Publ. 3, pp. 27-33.

Evans, S. H., Jr., and W. P. Nash, 1978, Quaternary rhyol ite from Mineral Mountains, Utah, U.S.A: Univ. Utah, Dept. of Geology and Geophysics, Rept. v. 77-10, DOE/DGE contract EY-76-S-07-1701.

Gertson, R. C., and R. B. Smith, 1979, Interpretation of seismic refraction profile across the Roosevelt Hot Springs, Utah and vicinity: Univ. Utah, Dept. of Geology and Geophysics, contract DE-AC07-78ET2832, p. 116.

Glenn, W. E., and J. B. Hulen, 1979, Interpretation of well log data from four drill holes at Roosevelt Hot Springs KGRA: Univ. Utah Res. Inst., Earth Sciences Laboratory Dept., DOE/DGE contract EG-78-C-07-1701, 74 p.

Glenn, W. E., J. B. Hulen, and D. L. Nielson, 1980, A comprehensive study of Los Alamos National Laboratory well C/T-2, Roosevelt Hot Springs KGRA, Utah, and applications to geothermal well logging: Univ. of Utah Res. Inst., Earth Science Laboratory Rept., DOE/DGE contract 4-N29-4088H-1.

Group Seven, Inc., 1979, Review of status of exploration north and east of Milford, Utah: prepared for Geothermal Kinetics, Inc., Phoenix, AZ.

Hoover, J. D., 1974, Periodic volcanism in the Black Rock Desert, Utah: Brigham Young Univ. Geol. Studies, v. 21, pt. 1, pp. 3-72.

Hulen, J. B., 1978, Stratigraphy and alteration, 15 shallow thermal gradient holes, Roosevelt Hot Springs KGRA and vicinity, Millard and Beaver Counties, Utah: Univ. Utah Res. Inst., Earth Sciences Laboratory Rept. 9, DOE contract EG-78-C-07-1701.

Keller, G. R., R. B. Smith, and L. W. Braile, 1975, Crustal structure along the Great Basin - Colorado Plateau transition from seismic refraction studies: Jour. Geophys. Res., v. 80, n. 8, pp. 1093-1098.

Lemmon, D. M., M. L. Silberman, and R. W. Kistler, 1973, Some K-Ar ages of extrusive and intrusive rocks of the San Francisco and Wah Wah Mountains, Utah: Utah Geol. Assoc. Pub. 3.

Lipman, P. W., P. D. Rowley, H. H. Mehnert, S. H. Evans, Jr., W. P. Nash, and F. H.Brown, 1978, Pleistocene rhyolite of the Mineral Mountains, Utah geothermal and archeological significance: Jour. Research U.S. Geol. Survey, v. 6, n. 1, pp. 133-147. 
Mundorff, J. C., 1970, Major thermal springs of Utah: Utah Geol. and Mineral Survey Water Resources Bu11. 13, $60 \mathrm{p}$.

Nehring, N. L., R. H. Mariner, L. D. White, M. A. Huebner, E. D. Roberts, K. Harmon, P. A. Bowen, and L. Tanner, 1979, Sulfate geothermometry of thermal waters in the western United States: U.S. Geol. Survey Open-File Report 79-1135, $11 \mathrm{p}$.

Nielson, D. L., 1978, Radon emanometry as a geothermal exploration technique: theory and an example from Roosevelt Hot Springs KGRA, Utah: Univ. Utah Res. Inst., Earth Science Laboratory Rept., DOE/DGE contract EG-78-C-07-1701, 31 p.

Nielson, D. L., B. S. Sibbett, D. B. McKinney, J. B. Hulen, J. N. Moore, and S. M. Samberg, 1978, Geology of Roosevelt Hot Springs KGRA, Beaver County, Utah: Univ. Utah Res. Inst., Earth Science Laboratory Rept., DOE/DGE contract EG-78-C-07-1701, $120 \mathrm{p}$.

01son, T. L., and R. B. Smith, 1976, Earthquake surveys of the Roosevelt Hot Springs and Cove Fort areas, Utah: Univ. Utah, Unpub. Report, N.S.F. contract GI-43741, v. 4, 82 p.

Parry, W. T., N. L. Bryant, R. E. Dedolph, J. M. Ballantyne, G. H. Ballantyne, D. T. Rohrs, and J. L. Mason, 1978, Hydrothermal alteration at the Roosevelt Hot Springs thermal area, Utah: Univ. Utah, Dept. Geology and Geophysics, DOE, contract EG-78-C-07-1701, $29 \mathrm{p}$.

Parry, W. T., W. P. Nash, J. R. Bowman, S. H. Ward, J. A. Whel an, N. L. Bryant, R. E. Dedolph, S. H. Evans, and D. Bowers, 1977, Part I-Geology and geochemistry of the Roosevelt Hot Springs, a summary, DOE/DGE Final Rept., v. 77-2, contract EY-76-S-07-1601, 12 p.

Petersen, C. A., 1975, Geology of the Roosevelt Hot Springs area, Beaver County, Utah: Utah Geology, v. 2, n. 2, pp. 109-116.

Robinson, R., and H. M. Iyer, 1979, Evidence from teleseismic P-wave observations for a low-velocity body under the Roosevelt Hot Springs geothermal area, Utah: Geothermal Resources Council Transactions, v. 3, 585 p.

Sass, J. H., D. D. B1ackwe11, D. S. Chapman, J. K. Costain, E. R. Decker, L. A. Lawver, and C. A. Swanberg, 1980, Chapt. 13-Heat flow from the crust of the U.S.: in Physical Properties of Rocks and Minerals, Y.S. Touloukian, W. R. Judd, and R. F. Roy, eds. in press, $58 \mathrm{p}$.

Shuey, R. T., D. K. Schellinger, E. H. Johnson, and L. B. Alley, 1973, Aeromagnetics and the transition between the Colorado Plateau and Basin Ranges Provinces: Geology, v. 11, pp. 107-110.

Sibbett, B. L., and D. L. Nielson, 1980, Geology of the Central Mineral Mountains, Beaver County, Utah: Univ. Utah Res. Inst., Earth Science Laboratory Rept., DOE contract DE-AC07-78ET28392, 42 p. 
Sil1, W. R., and J. Bode11, 1977, Thermal gradients and heat flow at Roosevelt Hot Springs: ERDA Technical Report: v. 77-3, contract EY-76-S-07-1601, 46 p.

Smith, R. B., and M. L. Sbar, 1974, Contemporary tectonics and seismicity of the western United States with emphas is on the Intermountain Seismic Belt: Geo1. Soc. America Bul1., v. 85, pp. 1205-1218.

Smith, R. L., and H. R. Shaw, 1975, Igneous-related geothermal systems, in White, D. E. and Williams, D. L. (eds.), Assessment of geothermal resources of the United States - 1975: U.S. Geol. Survey Circ. 726, pp. 58-83.

Swanberg, C. A., 1974, The application of Na-K-Ca geothermometer to thermal areas of Utah and the Imperial Valley, California: Geothermics, v. 3, n. 2, pp. 53-59.

Thangsuphanich, I., 1976, Regional gravity survey of the southern Mineral Mountains, Beaver County, Utah: Univ. Utah, unpub. M. S. thes is.

Ward, S. H., and W. R. Sill, 1976, Dipole-dipole resistivity surveys, Roosevelt Hot Springs KGRA: National Technical Information Service, Report 264-897/0, $52 \mathrm{p}$.

Ward, S. H., J. M. Bode11, W. D. Brumbaugh, J. A. Carter, K. L. Cook, T. J. Crebs, T. L. 01son, W. T. Parry, W. R. Sil1, R. B. Smith, I. Thangsuphanich, and A. C. Tripp, 1977, Part II-Geophysics of the Roosevelt Hot Springs thermal area, Utah: DOE/DGE Final Rept. v. 77-2, contract EY-76-S-07-1601, $25 \mathrm{p}$.

Ward, S. H., W. T. Parry, W. P. Nash, W. R. Sill, K. L. Cook, R. B. Smith, D. S. Chapman, F. H. Brown, J. A. Whelan, and J. R. Bowman, 1978, A summary of the geology, geochemistry, and geophysics of the Roosevelt Hot Springs thermal area, Utah: Geophysics v. 43, n. 7, pp. 1515-1542.

Wechsler, D. J., and R. B. Smith, 1979, an evaluation of hypocenter location techniques with applications to southern Utah: regional earthquake distributions and seismicity of geothermal areas: Univ. Utah, Dept. of Geology and Geophysics, DOE contract DE-AC07-78ET-28392, 131 p.

Wilson, W. W., and D. S. Chapman, 1978, Thermal studies at Roosevelt Hot Springs, Utah: Presented at annual SEG meeting, Nov. 1978, 56 p.

Yusas, M. R., and R. L. Bruhn, 1979, Structural fabric and in-situ stress analyses of the Roosevelt Hot Springs KGRA: Univ. Utah, Dept. of Geology and Geophysics, Univ. Utah, DOE/DGE contract ET-28392-31, Topical Rept. 78-17011 a. b. 5. 1, 62 p. 


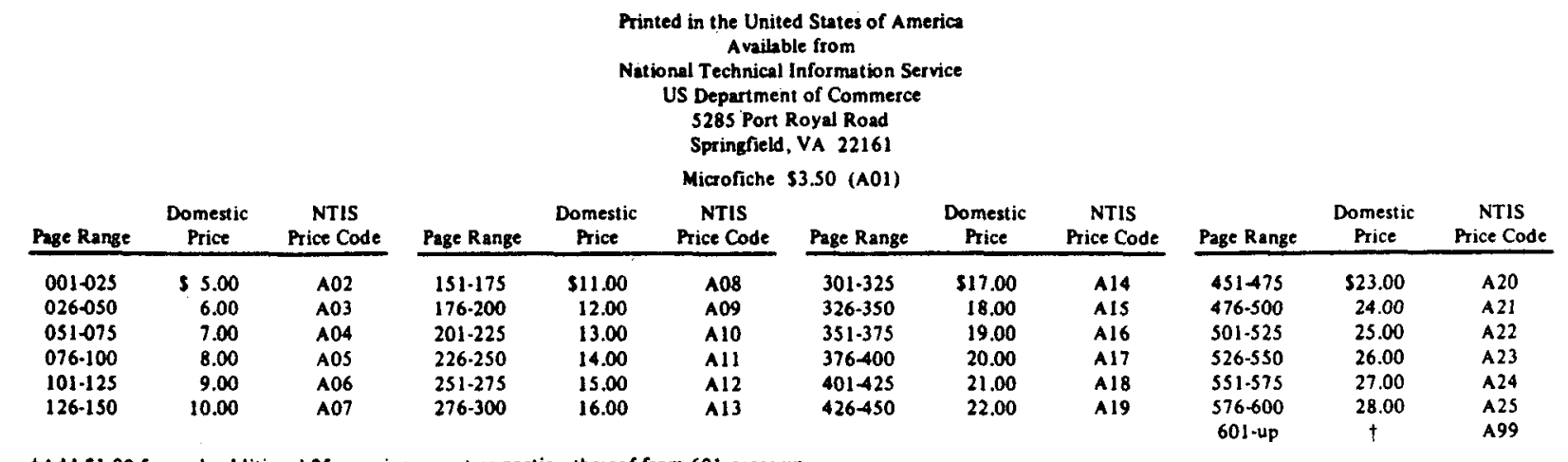

